NBER WORKING PAPER SERIES

\title{
THE SUBPRIME CRISIS AND HOUSE PRICE APPRECIATION
}

William N. Goetzmann

Liang Peng

Jacqueline Yen

Working Paper 15334

http://www.nber.org/papers/w15334

\author{
NATIONAL BUREAU OF ECONOMIC RESEARCH \\ 1050 Massachusetts Avenue \\ Cambridge, MA 02138 \\ September 2009
}

Thanks to Justin Haaheim for research support. The views expressed herein are those of the author(s) and do not necessarily reflect the views of the National Bureau of Economic Research.

NBER working papers are circulated for discussion and comment purposes. They have not been peerreviewed or been subject to the review by the NBER Board of Directors that accompanies official NBER publications.

(C) 2009 by William N. Goetzmann, Liang Peng, and Jacqueline Yen. All rights reserved. Short sections of text, not to exceed two paragraphs, may be quoted without explicit permission provided that full credit, including $\odot$ notice, is given to the source. 
The Subprime Crisis and House Price Appreciation

William N. Goetzmann, Liang Peng, and Jacqueline Yen

NBER Working Paper No. 15334

September 2009

JEL No. G01

\begin{abstract}
This paper argues that econometric analysis of housing price indexes before 2006 generated forecasts of future long-term price growth and low estimated probabilities of extreme price decreases. These forecasts of future increases in home-loan collateral values may have affected both the demand and the supply of mortgages. Standard time series models using repeat-sales indices suggested that positive trends had a long half-life. Expectations based on such models supported expectations that could lead to an asset bubble.

Analysis of data from the HMDA loan data base and LoanPerformance.com at the MSA level and at the loan level substantiates both supply and demand effects of past price trends in housing markets, particularly with respect to subprime mortgage applications and approvals. At the MSA level, past home price increases are associated with higher subprime applications and loan to value ratios. Approval probability of subprime loans was not affected by higher loan to value ratios. At the loan level, the approval probability of subprime applications is also positively associated with past home price appreciation. These results differ for prime mortgages.
\end{abstract}

William N. Goetzmann

School of Management

Yale University

Box 208200

New Haven, CT 06520-8200

and NBER

william.goetzmann@yale.edu

Liang Peng

University of Colorado at Boulder

419 UCB

Boulder, CO 80309-419

liang.peng@ colorado.edu
Jacqueline Yen

Yale School of Management

135 Prospect Street

P.O. Box 208200

New Haven, CT 06520-8200

Jacqueline.yen@yale.edu 


\section{Introduction}

The recent subprime mortgage crisis in the United States was preceded by a sharp increase in housing prices in the early 2000s. Economists at the time interpreted this increase variously as a classic housing bubble, the results of home-owner money illusion, or evidence of binding supply constraints in key housing markets. ${ }^{2}$ Regardless of which view is correct, one potentially important implication of the housing price run-up before 2006 is the effect it had on mortgage lending.

A key feature of house price indexes until 2006 is the degree to which they could be forecasted by past trends. In this paper, we examine the effect of this apparent predictability on perceptions about future house prices on the demand and supply of mortgages. While back-tests of forecasting models might have alerted market participants to the potential for model failure, empirical analysis of widely-quoted data sources like the Case-Shiller indexes and the OFHEO indexes clearly predicted continued growth. Risk models based on such forecasts suggested that housing would be good collateral for loans over multiple-year horizons.

On the demand side, extrapolation of past trends can influence both the level of household investment in housing and the risk characteristics of the applicant pool. First, expectations of positive future home price growth based on past trends renders housing a more attractive asset, suggesting that a household will increase allocation to housing over the near term. ${ }^{3}$ Applicants borrow to finance this allocation, which makes them riskier from a lender's perspective. Second, because the after-tax financial benefits of mortgaged home ownership are increasing in income, ${ }^{4}$ higher forecast returns may also bring more low-income loan applicants into the market. In this paper we look for evidence of increases in demand, applicant risk, and participation conditional on past trends.

On the supply side, mortgage lenders may interpret greater past price increases as evidence of lower default risk because the loan to value ratio is expected to fall with future house price increases. ${ }^{5}$ Consequently, lenders may accommodate the increased demand for mortgages because the expected future recovery from foreclosure is expected to exceed the outstanding mortgage principal. The supply of mortgage loans thus increases for all types of mortgages, but the effect may be most pronounced for borrowers with poor credit quality because of the participation effect.

To explore these hypotheses, we analyze 2006 Home Mortgage Disclosure Act (HMDA) mortgage data, historical Office of Federal Housing Enterprise Oversight (OFHEO) home price indexes for American metropolitan statistic areas (MSAs), and 2006

${ }^{2}$ cf. Case and Shiller (2003), Brunnermeier and Julliard (2008) and Glaeser, Gyourko and Saks (2005).

${ }^{3}$ For example, in a standard mortgage default decision model, changes in home prices are an important explanatory variable. Deng, Quigley, and Van Order (2000) provide a survey of the literature on these models.

${ }^{4}$ C.f. Goetzmann and Spiegel (2004)

${ }^{5}$ c.f. Doms, Mark, Furlong, Fred and Krainer, John (2007) 
LoanPerformance.com data on average loan to value ratios. We conduct MSA level and loan level analyses.

We first document the implication for forecasting based on reliance on standard econometric models using housing price data. Because of the strong autoregressive component in housing indices at the national and at the MSA level over the past 25 years most quantitative models using data up to 2006 forecast low probabilities for a crash in the near term. Ex post, these models were completely wrong. Ex ante, however, there was no consensus of model failure, even among professional economists. Our study first documents the (mis) performance of standard time-series models, and them explores the degree to which such mistaken forecasts may have affected demand and supply of capital.

We examine demand for mortgages using the HMDA mortgage application data aggregated at the MSA level. The variation in past home price growth across MSAs allows us to observe the relationship between home prices and demand for mortgages. Consistent with our demand story, 2006 mortgage applications for both prime and subprime mortgages are significantly and positively correlated with home price increases between 2000 and 2005. These results are robust to controls for demographic factors such as population and per capita income. In addition, we find evidence of increased household allocation to housing in MSAs with greater past home price appreciation. For example, the loan size to applicant income ratio is positively correlated with past home price appreciation. One possible story for the increase in leverage is that homeowners believed they could sell their home for more than the mortgage principal should they not be able to meet the payments.

This result is robust to controls for income per capita and the ratio of median home prices to median household incomes. We also find that the loan to value ratio for both prime and subprime applications is negatively correlated with past house price increases, suggesting that borrowers invested more of their own personal wealth in home equity. Further, we find that the home value to income ratio for both prime and subprime applications is positively correlated with past home price increases, showing that borrowers sought to purchase more expensive houses holding constant their incomes. Overall, the results indicate that in MSAs with greater past home price growth the demand for prime and subprime mortgages was higher and the applicant pool was riskier.

To analyze the effect of past home prices on mortgage supply, we turn to the HMDA mortgage approvals data. We note that the approvals are conditional on the quality and quantity of the applications across MSAs. ${ }^{6}$ In addition, competition among lenders will also affect approvals in the cross section. Cross-sectional regressions show that prime mortgage approvals are decreasing in past home price growth while subprime mortgage approvals are unchanged. This suggests that subprime lenders accommodated the extra demand in MSAs with higher past home price growth while prime lenders did not. Given

\footnotetext{
${ }^{6}$ For example, a positive shift in demand may bring less creditworthy investors to the mortgage market, which would result in a lower rate of mortgage approval if underwriting standards do not change. However supply effects might cause a loosening of credit standards, leaving total number of approvals unchanged.
} 
that applicant leverage was increasing in past home prices, prime lenders may not have accommodated the extra demand because it corresponded to applicants with higher loan to income ratios who were perceived as more risky. Subprime lenders, on the other hand, did accommodate the demand suggesting that they believed that future home price increases would compensate for the increased leverage of the borrowers.

When we compare the effect of leverage on prime and subprime approvals, we find that in MSAs with higher past price appreciation, prime lenders approve applications with lower loan to income ratios and subprime lenders approve applications with higher loan to income ratios. We also test the effect of past price changes on the loan to value ratios of approved prime and subprime mortgages. The coefficient on past price increases is negative and significant for both prime and subprime approvals, with and without controlling for loan to value ratios of applications. Since loans with lower loan to value ratios are less risky holding constant other factors, this result provides no evidence for looser underwriting standards used by either prime or subprime lenders. We also have robust results showing that the home value to income ratio of subprime and prime approvals is increasing in greater past price growth. This indicates that both prime and subprime lenders allowed borrowers to buy more expensive homes in MSAs with great past price increases.

Loan level probit analysis provides more direct evidence of supply effects. Past price appreciation significantly reduces the approvals of prime mortgages but significantly increases the approvals of subprime mortgages. The results are robust to controls such as loan to income ratios. The negative relation between past home price growth and prime approvals might be capturing the higher leverage and risk of prime applications in MSAs with greater past price rises. The positive relation between past home price growth and subprime approvals suggests that subprime lenders were more likely to accommodate increased demand in MSAs with greater past price growth despite the higher level of leverage in the applications.

Overall, our empirical evidence suggests that both subprime borrowers and lenders considered past housing returns as a factor in the home purchase process and the underwriting process - perhaps extrapolating the recent past as a forecast of future home values. In contrast, while prime borrowers considered past housing returns in their housing demand as well, prime lenders did not accommodate the demand and instead approved a smaller fraction of prime loans in MSAs with higher past housing returns and thus applications with higher leverage ratios.

The rest of the paper is organized as follows; Section II reviews the related literature. Section III discusses the predictability of home price indexes. Section IV examines the implication of using time-series models and housing indexes for evaluation of future collateral values; particular attention is paid to forecasts of housing price trends using data available immediately prior to the subprime crisis, and it considers whether model failure could have been reasonably anticipated. Section V examines the extent to which subprime mortgage applications and approvals were influenced by past price trends. Section VI considers alternative explanations. Section VII provides a discussion of the results and concludes. 


\section{Related Research}

Much of the recent research about the subprime crisis has focused on the process of origination and securitization in order to understand the roots of the disaster. Demyanyk and Van Hemert (2007) for example, show that the credit quality of securitized loans declined over the period 2001-2006. They find that home price declines after 2006 explain borrower delinquency and argue that price increases in the early 2000's masked the potential magnitude of the crisis. ${ }^{7}$ Rajan, Seru, and Vig (2008) show that from 19972006, lending rates increasingly relied on hard information and propose that future default rates were underestimated because of the lack of soft information. Mian and Sufi (2008) use a zip-code level data to test whether or not the credit expansion at the subprime level was due to credit supply or credit demand. Measuring unfulfilled demand as previously rejected mortgage applications, they find that lending standards loosened from 2001 to 2005 where previous unmet demand was high. They conclude that the increased issuance of subprime mortgages was due to an increase in the supply of credit as opposed to an increase in demand for credit. They conjecture that the growth in housing price indexes in markets with high subprime issuance was a result of greater credit access.

Other researchers have focused on the role that the emergence of a secondary market played in supplying the credit. Gabriel and Rosenthal (2006) find evidence that securitization of subprime mortgage loans greatly increased access to credit among lowincome homeowners - consistent with stated government social policy. ${ }^{8}$ Keyes et. al. (2008) look at the risks created by the securitization by exploring the exposure of the secondary mortgage market to moral hazard in loan origination. They find that securitized loans were more likely to default following the crisis, consistent with a story of lower underwriting standards.

The relative contribution of the current paper is to focus on the role past home price appreciation played in both the demand and the supply of prime and subprime mortgages. It is limited to the extent that we develop neither a formal tenure choice model nor a formal mortgage default model. We focus instead on a specific input to such models. We argue that price index appreciation and apparent long-term predictability were potentially important factors in the decision processes of many market participants, and we test some empirical implications of this argument. In particular, we focus on the demand side and suggest a story where individuals made a rational investment decision when applying for a prime or subprime mortgage. The inclusion of prime mortgages in our analysis also provides a benchmark for interpreting the subprime mortgage results.

\footnotetext{
${ }^{7}$ Their findings are consistent with the considerable evidence that home prices are important co-determinants of default. See, for example Downing, Wallace and Stanton (2005) and Crews Cutts and Van Order (2005).

8 The policy implications of the subprime mortgage market are further explored in Wachter, Russo and Hershaff (2005) and Calem, Gillen and Wachter (2003).
} 
Our assertion is that expectations of future appreciation, based upon extrapolation of past trends, may be a factor in the decision functions of both home buyers and mortgage lenders, and help explain several of the recently-documented empirical findings, including the deterioration of credit standards and the increase in the supply of credit to previously constrained markets. While individual homeowner exuberance or irrationality may have played a role in stimulating the demand for housing and mortgage credit in the 2000s, marginal home buyers may rationally decide to become home owners or existing home buyers may increase mortgage leverage when the expected future appreciation is high. Moreover, while moral hazard has been advanced as one explanation for the deterioration of credit standards, evidence that credit standards seemed looser in MSAs with greater past price rises suggests that the decision functions of lenders and originators are affected also by the expectation of future house price appreciation.

\section{Predictability of House Price Indexes}

Most current measures of home price appreciation are based upon the repeat-sales regression [RSR]. ${ }^{9}$ The RSR relies upon repeated sales of individual properties to estimate a time-series of past rates of capital appreciation. The well-known Case-Shiller indexes are based upon the RSR, as are the OFHEO indexes used to monitor the capital adequacy of the housing agencies, Fannie Mae and Freddie Mac.

Case and Shiller (1989) found that RSR housing indexes follow an autoregressive process, rendering them highly predictable. In part, this predictability is an artifact of the estimation procedure that by necessity has difficulty in identifying closely-timed shocks. ${ }^{10}$ However, the inertia in housing indexes is also due to actual economic phenomena. Housing is not as efficient, nor as liquid as the stock market. News is not rapidly impounded in prices but instead manifests itself slowly. Unlike securities markets, housing markets have fewer pure speculators, housing is difficult to sell short, time on the market matters, and there are important factors of individual preferences and beliefs. People are reticent to sell their homes for many reasons other than price. Besides inducing inertia in housing indexes, these factors may also distort inferences regarding the value of a home in the market as collateral. ${ }^{11}$ Case and Shiller (2003) argue that the inertia in housing prices provides a natural condition for the development of a bubble because of the potential for overly optimistic beliefs about future price increases to form.

One problem with relying on housing indexes as evidence of market values is that they are conditioned upon market liquidity. Crashes only appear to develop slowly in house price indexes because transactions decrease as buyers are unwilling to recognize a loss. ${ }^{12}$ Thus, an econometric forecast that ignores the potential for illiquidity can be misleading. Such liquidity-adjusted price indexes were not widely available for a broad spectrum of

${ }^{9}$ Cf. Bailey, Muth and Nourse (1963).

10 cf. Geltner (1997).

${ }^{11}$ Cf. Lin and Vandell (2007), Goetzmann (1993).

12 Goetzmann and Peng (2005), Clayton, Miller and Peng (2008) 
housing markets before 2006. In other words, market participants may have been making unconditional forecasts based on conditional data.

\section{Time Series Forecasts}

\section{IV.1 Data}

Monthly Case-Shiller indexes for twenty of the major metropolitan areas in the United States are available for download at the S\&P website. ${ }^{13}$ Quarterly indexes for all MSAs in the United States, and for each state, are available from the OFHEO website. ${ }^{14}$ The major difference between these two sources is the underlying data. The OFHEO data is constructed from transactions or appraisals associated with mortgages purchased or insured by Fannie Mae or Freddie Mac since 1975. These mortgages are overwhelmingly "prime" loans, and thus by definition not subprime. The data used to construct the Case-Shiller indexes are not restricted to transactions associated with prime mortgages, nor do they rely on appraised values.

\section{IV.2 Trends}

Figure 1 plots the Case-Shiller indexes with a common value in December 1999. The figure suggests that the price appreciation in housing after 2000 on average was higher than before 2000 - at least up until the recent crash.

More distinctive is the inertia in the series. This may be partly due to the fact that Case and Shiller use a three-month moving average, but adjusting for this, the momentum in the indexes still seems powerful. Ignoring high-level econometrics for a moment, cover up the graph from 2006 on and ask yourself whether you would have predicted a significant price correction in the next two years. There was little historical precedent for a major correction. One could only point to the price slump in some markets after 1990 as a precedent and a few other regionally limited events.

Figure 2 provides additional insight into the earlier price dynamics. It is constructed by identifying all the OFHEO MSA indexes for which continuous data are available between 1980 and 2005. Since there are more than 380 MSAs in the OFHEO data set, a plot like Figure 1 is not meaningful. The K-means clustering algorithm is applied ${ }^{15}$ to aggregate the data. The algorithm groups indexes by minimizing within group sums of squared deviations from the group mean index. An arbitrary choice of five group centers allows sufficient range of performance. At least three distinct trends can be seen. One set of cities, mostly in Texas, Oklahoma and Louisiana, peak about 1986 and then drop by a factor $10 \%$ to $20 \%$. Another group, comprising mostly of California cities and Boston peak around 1990 and dropped by a similar magnitude over the next five years. A group comprising mostly of Florida cities had a dramatic run-up in the 1980s, then flattened out

\footnotetext{
${ }^{13}$ http://www2.standardandpoors.com/portal/site/sp/en/us/

page.topic/indexes_csmahp/0,0,0,0,0,0,0,0,0,1,1,0,0,0,0,0.html

${ }^{14}$ http://www.ofheo.gov/hpi.aspx

${ }^{15}$ Which intersect, by construction, in 1995.
} 
after 1990. Two groups of mostly "Heartland" cities showed relatively consistent performance over the period. Thus, twenty-five years of housing data demonstrates some macro-economic dynamics, although slumps on portfolios of cities were on the order of $10 \%$ to $20 \%$ nominal depreciation over horizons of five years.

This is not to say that cross-sectionally, individual cities did not experience extended periods of real price depreciation. Other studies of these data show that homeowners in specific cities have historically faced significant housing price risk. ${ }^{16}$ Nevertheless, it would have been easy to believe that the trends in these figures provided some basis for estimating the timing and magnitude of future price declines - particularly since the OFHEO figures were produced by a government agency for the specific purpose of evaluating precisely such risk.

\section{IV.3 Risk and Return}

Figure 3 plots the annualized arithmetic mean return and standard deviation of the CaseShiller indexes for which data are available from 1987 through 2005. Over this time period, the arithmetic annual growth in the CPI index was 3.7\%, so nearly all of the MSAs experience real price appreciation in the time period. The Case-Shiller composite index of the ten cities experienced a $6.7 \%$ return and a $2.25 \%$ standard deviation. The standard deviation is obviously a misleading indicator of long-term risk because of the documented inertia in the time-series.

Figure 4 is a similar plot for the OFHEO indexes, with the MSA corresponding to the Case-Shiller indexes labeled. For the most part, the Case-Shiller cities had higher returns compared to the typical city in the OFHEO sample. The relative volatility of Miami and Las Vegas are noteworthy.

\section{IV.4 Time-Series Dependency}

Figure 5 plots the monthly housing returns for the Case-Shiller Los Angeles series (from 1987) against its lagged values for horizons up to 25 months. The plots for the other cities are not reported, but the Los Angeles return series inter-temporal dependency is fairly representative of that of other Case-Shiller indexes. The correlation is reported in the upper left corner of the plot. Even at a two-year horizon, the correlation is positive, suggesting that current trends are sustained over multiple year horizons. Figure 6 plots the quarterly housing returns for the OFHEO Los Angeles series (from 1980). The lag correlation now extends out to 24 quarters - more than six years. Correlations after the first three years are negative, suggesting mean reversion in the LA housing market at long horizons.

Taken together, the monthly and the quarterly correlations of lagged returns suggest that a time series' forecast based on an ARIMA model is potentially useful.

\section{IV.5 Forecasting Methodology}

${ }^{16}$ Caplin, Chan, Freeman and Tracy (1999), Goetzmann and Spiegel (2002). 
Undoubtedly some mortgage market participants used state-of-the-art forecasting tools to predict defaults and to assess future collateral risk. By 2006, not only was the inertia of housing indexes well known, but the link between house price values and defaults had been well studied ${ }^{17}$. Thus, predicted home values were natural variables to include in both a mortgage default and a collateral recovery model. In this section we estimate future values using a simple ARIMA specification to model the historical structure, and then use that model to forecast future index values and confidence bands. ${ }^{18}$ This standard model allows for lags, differencing, an intercept term and a moving average component. The long-term trends in the figures above suggest that multiple-year lags may contain useful forecasting information. Thus, the maximum number of lags, up to 24 months, is used for the Case-Shiller data. In all cases the data are first-differenced, an intercept included, and for most, a three-month moving average is employed, reflecting the fact that housing prices have expected positive trends, and that the Case-Shiller methodology uses a three month moving average. ${ }^{19}$

\section{IV.6 Forecast at the End of 2005}

In this section we estimate confidence bounds for nineteen of the twenty Case-Shiller indexes with the end of 2005 as the forecasting point. ${ }^{20}$ Figure 7 plots the forecasted trends, the actual trends, and the confidence bounds at two standard errors above and below the trend. In fifteen out of the nineteen cases the actual index value ended below the lower confidence bound, suggesting that the ex ante forecaster would have regarded such an event to be highly unlikely. The ARIMA model forecasted positive future price increases in all nineteen of the twenty cities. While some MSAs like Seattle, Washington were forecast to grow as much as $40 \%$ in price over three years, many MSA's were relatively flat, and expected total growth over three years was in the range of $3 \%$ to $6 \%$.

More relevant for the mortgage lenders and borrowers at the beginning of 2006 was the ex ante probability of a decrease in house prices over a three year horizon. In some markets the forecasting model suggested this was a highly unlikely event. For seven markets the chance of a drop in value at the end of a three year period was estimated at less than 5\%. However, for many large markets, including Los Angeles, San Diego, San Francisco, New York, Boston and Los Vegas, the models would have suggested that a drop in prices in the range of $15 \%$ to $25 \%$ lay within the realm of possibility. The

${ }^{17}$ c.f. Capozza, Kazarian and Thomson (1997), Downing, Stanton and Wallace (2005) among others.

18 The details of the estimation may be found in the documentation for the R statistical language. Shumway and Stoffer (2006) point out inconsistencies in the use of the R

ARIMA code for differenced series estimation, and offer a modified code to overcome these issues. This paper used their code available at http://www.stat.pitt.edu/stoffer/tsa2/index.html. The prediction uses a Kalman filtering method, and does not take into account parameter uncertainty associated with the timeseries model.

${ }^{19}$ Eight MSAs were estimated with $\operatorname{ARIMA}(18,1,3)$, five with $\operatorname{ARIMA}(12,1,3)$, one with $\operatorname{ARIMA}(6,1,3)$, two with $\operatorname{ARIMA}(3,1,3)$ and four with $\operatorname{ARIMA}(3,1,0)$.

${ }^{20}$ The time series for Dallas is too short to estimate the ARIMA model. 
standard errors in the ARIMA model would have warned of the possibility of a significant drop in several major markets on the order of magnitude of previous housing market crashes. Thus, it is difficult to argue that the models as such provided unreasonable predictions of risk and return, given historical experience. Ex post, one could argue that the assumption of normality in the ARIMA residuals, and the failure to account for parameter uncertainty in the model resulted in overly tight confidence bands. ${ }^{21}$ How current were robust estimation methods among market participants at the time? It is difficult to know. Using the model as a general guide to risk evaluation does not seem to have been entirely foolhardy, except with the hindsight of the dramatic market crash. Would an expert at the end of 2005 have had any reason to doubt the validity of the data or the model? Some evidently did.

Certainly Case and Shiller (2003) sought to use alternative data collected from surveys of homeowners to identify a bubble in the housing market before 2006. They polled homeowners about their expectations of future price increase in various cities. The expectations for growth over the next ten years in many cities exceeded $10 \%$ per year. They interpreted the evidence as suggestive of an economic fallacy, since the longer term growth in home prices had been below $10 \%$. While is it not difficult to believe that homeowners had an unsophisticated anticipation of future price increases in the early 2000's it is harder to believe that financial institutions and professional risk managers would get swept up in irrational beliefs about future home prices without relying on the analysis of hard data and reliable statistical models. The rational calculation of default probability and recovery through foreclosure should provide an institutional constraint on the consequences of individual naiveté with respect to the risk and return of investing in a home.

\section{IV.7 Model Validity}

A natural test in 2006 of the reliability of housing price forecasts might have been to see whether a time-series econometric model did a reasonable job at bounding the performance of housing markets in previous years. Using the same methodology as above, we made five-year ahead forecasts using data prior to 2000. Good model performance is measured by the frequency of the housing index lying within a four-sigma band. Figure 8 shows the results of this test. Six of the nineteen markets exceeded their two-sigma confidence band. Fourteen of the nineteen indexes exceeded the five-year forecast. The rate of model failure should have given an analyst grounds to doubt the reliability of the confidence bands, at the very least.

A counter-argument is that we cannot presume that each observation is independent. Thus, even though roughly a third of the markets exceeded their bands this would be insufficient to reject the validity of the model for risk assessment. In fact, as the above analysis suggests, housing markets were not independent. However, for purposes of risk assessment, high correlation across markets should be grounds for greater caution, not greater comfort. It simply means that the historical data is insufficient to provide a reliable test of model validity.

${ }^{21}$ See Brunnermeier and Julliard (2008) and Goetzmann and Valaitis (2006) for examples of robust modeling of housing trends. 
Should we be skeptical of the ARIMA forecasting model in general? Is it just a poor tool for analyzing housing price trends? To consider that possibility, we step back to 1995. At this point, fourteen series' are available. A five-year forecast, shown in Figure 9, compared with the actual performance to the year 2000 presents a slightly more reasonable picture of model performance. Three series' exceeded their confidence bands, but only just barely in every case. One thing to note is that the model consistently underestimated the growth of housing markets by extrapolating the past long-term drift that incorporated significant historical slumps in several cities. On balance, there might have been moderate grounds for some skepticism about model reliability, but the strong evidence for inertia in housing price indexes would not have been disputable.

\section{Market Effects}

\section{V.1 Past market growth and demand for mortgages}

So far, we have shown that the pre-2006 house price indexes demonstrated a strong, multi-year, lagged dependency suggesting that they could be forecast out to multiple year horizons. A standard ARIMA forecast indeed predicted future price increases in virtually all the major Case-Shiller markets, and suggested negligible probabilities of a crash. An important caveat is that back-tests of the model might have provided grounds for skepticism, as well as the evident lack of sufficient time-series data to accurately estimate long-horizon dependencies. In this section we consider the implications of reliance on these models.

Case and Shiller (1993) argue that the high level of index predictability might lead market participants to buy in anticipation of future price increases and to believe that they could sell before a price downturn - classic asset bubble expectations. Therefore, holding constant other factors that affect the home purchase decision, such as income, LTV, etc, the greater past price rises are, the more likely potential buyers would like to become home owners. Consider a marginal buyer who has a negative value of owning a home - the expected cost caused by delinquency and thus foreclosure is sufficiently high to offset the expected benefit of ownership. A greater anticipated rise in value would increase the expected benefit of home ownership and reduce the expected cost. The cost will decrease even though the probability of delinquency may be the same because when delinquency happens, the owner has a better chance to sell her house for a profit instead of going through a foreclosure. Additionally, expected home price gains increase the leverage a home owner could bear without increasing the expected cost.

We hypothesize that the increasing participation and increasing mortgage leverage due to greater anticipated future price increases had an effect on the demand for mortgages. First, the total demand for mortgages, being prime and/or subprime, would increase with anticipated future price increases. In addition to the increased number and volume of applications, increased demand may manifest itself in higher spending on housing as captured by higher loan to income ratios, lower loan to value ratios, and higher value to income ratios. Second, we expect the riskiness of the mortgage applicant pool increase due to increased participation and allocation to housing. We test both aspects of the 
demand effect using 2006 HMDA loan level data. ${ }^{22}$ Subprime loans are identified using the U.S. Department of Housing and Urban Development's subprime lender list ${ }^{23}$.

\section{V.2 Empirical evidence on mortgage demand}

Table 1 reports univariate and multivariate cross-MSA regression results predicting the demand for prime mortgages in 2006. The log of the number of loan applications and the log of the dollar volume of loan applications are regressed on past price rises from 1999:4 to 2005:4 (the log of the ratio of the OFEHO house price index in 1999:4 to the index in 2005:4) and an additional set of variables. The univariate regressions show a positive correlation between the demand for prime mortgages and past price increases - the coefficient of past price change is positive and significant at the $1 \%$ level. However, this positive relationship might be induced by any one of a number of other variables. For example, big cities with more home buyers would simply have higher demand for mortgages, and cities with higher employment rates and higher income would also have more demand. To account for these effects, we include the following control variables in the multivariate regressions: the log of the population of the MSA from the 2006 American Community Survey dataset [ACS], the log of the MSA unemployment rate in 2006 from Bureau of Labor Statistics (BLS), the log of the percentage of the population over 65 from ACS, the log of the percentage of the population with a high school degree from ACS, and the log of income per capita (in \$ thousands) from ACS.

The multivariate regressions in Table 1 also provide strong evidence that past price rises increase the demand for prime mortgages. While the coefficient of past price change is smaller in the multivariate regressions than in the univariate regressions, it is still positive and significant at the $1 \%$ level. It is worth noting that adding control variables dramatically increases the $\mathrm{R}$ squares - from 0.11 for loans and 0.25 for volume in the univariate regressions to 0.93 for both loans and volume in the multivariate regressions. Further, the coefficients of the control variables seem sensible. A MSA with a larger population, a lower unemployment rate, and a larger portion of the population below 65 years old would have higher demand for prime mortgages.

Table 2 reports similar univariate and multivariate regressions of the demand for subprime mortgages in 2006 as measured by the number and dollar amount of applications. Additional regressions control the demand for prime mortgages. The regressions provide strong and robust evidence that past price rises increase the demand for subprime mortgages. The coefficient on past price change is significant not only when controlling for demographic factors, but when controlling for prime mortgage applications. The prime mortgage applications should capture any missing factors that would influence broad demand for home mortgages in the MSA, including any effects due to constraints on growth. Controlling for prime mortgage applications has another

${ }^{22}$ Available from www.ffiec.gov/hmda/hmdarawdata.htm\#by_msa. Avery, Brevoort, and Canner (2007) estimate that $80 \%$ of all home lending in the U.S. is covered by the 2006 HMDA data set. All data in this paper uses loans marked for home purchase. We also define "approved" loans as those that are ultimately originated to avoid double counting loans approved by multiple institutions.

${ }^{23}$ Available from www.huduser.org/datasets/manu.html 
useful interpretation in the context of the Case and Shiller bubble hypothesis. If one assumes that unreasonable extrapolation of past price increases is the same for prime and subprime borrowers, then the prime loan variable should capture demand-side "irrational exuberance." The remaining price rise effect is either due to even greater irrationality on the part of the subprime borrower or it is due to the greater willingness of the subprime lenders to approve applications, i.e. relaxation of constraints on the capital supply side. The results suggest that past price changes affect the demand for subprime mortgages more strongly than the demand for prime mortgages.

We next test the second aspect of the demand effect: that the average riskiness of loan applications increases with past price appreciation. We use the log of loan size to applicant annual income ratio as a proxy for riskiness of loan applications and a measure of mortgage leverage. It is plausible that, holding constant applicant income and other factors, the greater the loan size, the higher the probability of delinquency and default. Therefore, the loan to income ratio is correlated with riskiness of loan applications. Table 3 reports univariate and multivariate regressions of the average of the log of loan size to income ratio on the past price change for both prime and subprime mortgage applications. Table 3 provides strong evidence of a riskier applicant pool in MSAs with higher past price appreciation: the coefficient of past price changes is positive and significant at the $1 \%$ level for both prime and subprime mortgages. The coefficients on the control variables also appear to be sensible. For example, the greater the unemployment rate in an MSA, the higher the average riskiness of mortgage applicants in the MSA (higher loan to income ratios). We also confirm that the result is capturing an applicant's desire to borrow more (the spending effect), given her income, and not the presence of more expensive houses. The coefficient of past price changes is still significant when we control for the log of the ratio of median existing single family home price to median household income using data from economy.com.

We further test the hypothesis that borrowers tend to buy more expensive homes, given their loan amount and income, in MSAs with greater past price appreciation. We run two types of regressions. Table 4 regresses the loan to value ratio on past price changes. The average loan-to-value ratios at the MSA level are provided by LoanPerformance.com. We expect to see that the loan to value ratio is decreasing in past price appreciation. This would be evidence that borrowers want to invest more in home equity, which means borrowers want to buy more expensive homes given the loan amount. Results in Table 4 support the hypothesis. The coefficient on past price appreciation is negative and significant for both prime and subprime loan applications. The result is robust to a control for the ratio of median existing single family home price to median household income, so the relation is not due to higher home prices.

Table 5 regresses the home value to income ratio on past price changes, and tests the hypothesis that borrowers want to buy more expensive homes, given their income. The home value to income ratio for an MSA is constructed by dividing the average loan to income ratio for this MSA in Table 3 with the average loan to value ratio for this MSA in Table 4. The positive and significant coefficient of past price changes indicates that borrowers want to buy more expensive homes given their income. The result is robust to the control for the ratio of median single family home price to median household income. 
In sum, Tables 1 through 5 provide evidence for three aspects of the demand effect. First, demand for mortgages is increasing in past price appreciation. Second, the average riskiness of mortgage applications is increasing in past price appreciation. Third, both prime and subprime borrowers want to buy more expensive homes given their income and loan amount in MSAs with greater past price increases.

\section{V.3 Empirical evidence on mortgage supply}

The apparent predictability of future price changes might also affect lenders' behavior. Past price rises could support a lender's view that the collateral value upon which the cost of future borrower default depends will be worth as much or more than the original loan value as long as the positive serial correlation in lagged returns is reliable. As a result, holding constant other factors, lenders may be more willing to make loans (more relaxed underwriting standards) in MSAs with high past price appreciation. The increased supply of mortgages should then appear in higher approval and origination rates.

Table 6 tests if past price appreciation increases prime loan approvals, which are measured by the number of loans approved and the total dollar loan amount. In Table 6, when we do not control for loan applications, more loans are approved in MSAs with greater past price increases. However, when we control for loan applications, past price increases has a negative coefficient. This indicates that the prime lenders approve a smaller portion of applications in MSAs with greater past price appreciation. Relating this result with our earlier finding that the riskiness of applications is increasing in greater past price changes, we have no evidence to support the hypothesis that prime lenders accommodated increased demand in high-growth MSAs.

Table 7 conducts the same analysis on subprime loans. The coefficient on past price increases is positive and significant when we do not control for applications, but is insignificant (positive and significant in one specification) once we control for demand as measured by the volume of applications. This result provides weak evidence that subprime lenders accommodated increased demand. Despite the higher leverage and thus greater riskiness of loan applications in MSAs with greater past price appreciation (which we established in Table 4), subprime lenders approve roughly the same portion of applications.

Table 8 formally tests the differences between prime and subprime approvals. The dependent variable is the approvals for subprime loans minus the approvals of prime loans. The regressions control for the difference between subprime and prime applications. Table 8 shows that the coefficient on past price increases is positive and significant in all specifications. This result shows that subprime lenders approve a larger portion of applications than prime lenders in high-growth MSAs.

We further consider whether the leverage of approved loans relates to past price changes for both prime and subprime loans. Table 9 regresses the loan to income ratios of approved loans on past price changes, with and without controlling for the loan to income ratios of applications. For prime loans, when we do not control for the loan to income ratio of applications, past price changes have a positive and significant coefficient. However, once we control for the loan to income ratio of applications, past price changes 
have a negative and significant coefficient. This result suggests that prime lenders approve applications with lower loan to income ratios in MSAs with greater past price changes. This is consistent with the notion that prime lenders did not use looser underwriting standards in such MSAs. However, in the same regressions for subprime approvals, the coefficient on past price increases is positive and significant with and without controlling for the loan to income ratio of applications. This result shows that subprime lenders approved application with higher leverage in MSAs with greater past price changes, which is consistent with the notion that subprime lenders used looser underwriting standards in high-growth MSAs.

Table 10 tests whether past price changes are related to the loan to value ratio of approved prime and subprime mortgages. The coefficient on past price increases is negative and significant for both prime and subprime approvals, with and without controlling for the loan to value ratios of applications. Because loans with lower loan to value ratios are less risky holding constant other factors, Table 10 provides no evidence of looser underwriting standards among both prime and subprime lenders. Though applicants in MSAs with greater home price appreciation wanted to buy more expensive houses for a given loan amount, lenders did not accommodate this spending demand.

Table 11 tests whether the ratio of home value to borrower income of approved prime and subprime mortgages is related to past price changes, with and without controlling for the ratio of value to income in applications. The results are consistent. For both approved prime and subprime loans, the value to income ratio is increasing in greater past price changes. This indicates that for a given income, both prime and subprime lenders allowed borrowers to buy more expensive homes in MSAs with great past price increases.

\section{V.3 Loan level evidence on mortgage supply}

We also test the supply effect at the loan level using probit analysis on the approval/rejection of loan applications. The analysis uses all mortgage applications for purchasing owner-occupied single family houses secured by first liens. Separate probit analysis is conducted for prime and subprime applications. Dependant variables are 1 if an application is approved and 0 if not. Explanatory variables are past price rises in the MSA of the application, the log percentage of the minority population in the census tract of the loan application, HUD median family income in dollars (log) in the MSA of the loan application, the log of the percentage of tract median family income compared to MSA/MD median family income, the log of the size of the application to the income of the applicant, and a dummy that equals 1 if preapproval was requested. additional explanatory variables control for the riskiness of applications. Note that the data do not allow us to control for the loan to value ratio at the loan level.

Table 12 reports the probit analysis for prime and subprime mortgage applications. Past price rises have opposite effects on the approval of prime and subprime applications. Greater price rises reduce the approval probability for prime applications and increase the approval probability of subprime applications. This indicates significant distinctions between prime and subprime lenders. In the context of our earlier results that loan applications tend to be more risky in MSAs with greater past price increases, the results 
in Table 12 do not provide evidence for looser underwriting standards among prime lenders but do provide evidence of looser underwriting standards among subprime lenders.

Coefficients on the other explanatory variables in the probit analysis are sensible. A lower percentage of minority population, a higher median income, a larger ratio of tract to MSA median income, and a lower loan to income ratio increase the probability for an application to be approved. The results seem to suggest that the control variables effectively help proxy for riskiness of applications.

To visualize the effects of past price rises on subprime approvals, Figure 10 plots the relationship between the growth of the OHHEO indexes over the period 2000 to 2005 against the log dollar amount of subprime loans originated in 2006 for new home purchases (in thousands). The positive relationship in Figure 10 between past price growth and dollar of subprime issuance is clearly evident. ${ }^{24}$

While there is evidence in the behavioral finance literature that lower-income people are less financially sophisticated ${ }^{25}$, our empirical analysis indicates that past price appreciation affects not only the demand for subprime mortgages but subprime mortgage lenders, though the evidence suggests that lenders may have merely accommodated increased demand because of increased capital. Mian and Sufi (2008) in fact show that capital supply constraints were meaningful in the period, although they also document a trend towards looser standards. Thus our results provide strong evidence that the binding but loosening supply constraint based upon forecasts using house price indexes as inputs helped contribute to more subprime applications and also possibly approvals in "hot" cities as opposed to only overly-optimistic buyer demand. The increased capital story does not explain why subprime mortgage approvals were more sensitive to higher demand in MSAs with higher past price appreciation than prime approvals.

\section{Alternative explanations}

\section{VI.1 Moral Hazard}

Consider the Keys et. al. (2008) explanation for the volume of subprime issuance: that loan originators did not care about the quality of the loans because there was a ready market to securitize them. Our empirical results do not rule out this moral-hazard explanation, but we find evidence that may require further elaboration of the moral hazard model. If subprime lenders simply made every loan they could, regardless of the probability of default or the expected recovery upon default, we would not expect to see approval probability of subprime application correlated with past price increases at the loan level. Our empirical evidence substantiates the effects of past house price changes

\footnotetext{
${ }^{24}$ Susan Wachter also documents this correlation for housing and mortgage data in 2002 in her presentation to the Evolving Housing Finance Marketplace Roundtable, January 16, 2008.

${ }^{25}$ For example Dhar and Zhu (2006)
} 
on both mortgage applications and approvals, which suggests that extrapolations of past price increases in these markets seem to be consistent with the rationality of both borrowers and lenders - if one can call trust in price extrapolation rational. Work needs to be done to distinguish between reliance on a model and lender moral hazard.

\section{VI.2 Reverse causality}

Mian and Sufi (2008) hypothesize that the price growth from 2000 to 2005 was caused by increasing access to credit, which in turn pushed up housing prices. As with the moral hazard story, we do not rule this hypothesis out. In fact, a classic bubble would include prices increasing on expectations of future price rises and vice-versa. Our examination of the 1995 to 2000 price indexes suggests, however, that some housing markets were rising before the widespread access to credit by subprime borrowers. An important implication of the credit-driving-prices story in the context of the current paper is that it raises the question of reverse-causality in the cross-sectional regressions - that the relationship we document is an artifact of past lax credit access (where past credit access is proxied by 2006 subprime issuance) having driven up prices.

In some sense, subprime credit issuance in 2006 was forward-looking, regardless. When

forecasting future growth and risk of loss, a lender might be wise to factor in how much of that forecast is predicated on continuing past credit policies, since a sudden change in market conditions - like a credit crunch, or a drop in demand for mortgage-backed securities would represent a regime-change that should alter parameters in a forecasting model. However, if lenders expected the conditions that led to past price increases in certain markets to continue (including lax credit standards) then extrapolation of past trends would remain a relevant input to lending risk analysis.

\section{Discussion}

\section{VII.1 Interpretation of Basic Results}

This paper document results regarding the effects of past house price changes on applications and approvals of both prime and subprime mortgages. First, econometric models applied to housing index data up to 2006 predicted future price increases and low probabilities of an extreme crash in home values. Second, past price appreciation increased mortgage applications, the leverage of borrowers, and the prices of purchased homes (with borrower income and loan amount held constant). Third, past price changes evidently affected the approvals of prime and subprime applications differently. We have no evidence that prime lenders used looser underwriting standards, but we do have some evidence for subprime lenders. Overall, our analysis provides evidence of extrapolation of past price gains by subprime borrowers and likely lenders.

We also considered alternative explanations for theories about the subprime crisis, and the observed correlations documented in the cross-sectional regressions, including moral hazard and reverse causality. Moral hazard as the cause of the subprime crisis would require an additional explanation regarding why the approval probability of subprime applications at the loan level is correlated to past house price increases. The reverse 
causality argument is one possible additional explanation. If both were true, it would suggest a deeply dysfunctional, perhaps even cynical capital market. We cannot rule this possibility out, but the hypothesis we propose is at least consistent with lenders having the intention of quantifying and managing risk.

\section{VII.2 Implications for Risk Management}

The evidence in this paper also raises the broader issue of the role of statistical analysis of historical data for the purposes of risk management. The difference between uncertainty and risk is the potential for expressing the range of future outcomes quantitatively. The development of good housing indexes made econometric forecasting possible, but it also created the potential for risk models to fail. It is thus a strange twist that the technology for quantifying risk led to a reliance on models that are, themselves, liable to failure.

The larger irony of the subprime crisis is that it struck the financial markets at a time that might otherwise have been considered a revolution in risk management. In institutional portfolio management, the world had finally rejected security specific risk measures "safe" securities lists - in favor of prudent portfolio diversification. ${ }^{26}$ Even as institutional managers extended their portfolios beyond stocks and bonds into the world of hedge funds, they tracked such things as their exposure to numerous risk factors: interest rate shocks, market moves, emerging market events, shifts in inflation, the value premium, the size factor and many more. Indeed the complaint heard most in the early part of the decade was not about the lack of risk measures, but rather that risk assessment had come to dominate return generation in portfolio decision-making.

In banking, Basel II had been considered a major new paradigm for the institutional evaluation of risk. It validated a "value-at-risk" approach for determining bank capital requirements, encouraging institutions to build models relying upon the statistical analysis of historical data.

In the domain of housing and mortgages, one would have been inclined to trust in the nearly two decades of experience by investment banks with mortgage-backed securities issuance, and to take comfort in the existence of well-capitalized arbitrageurs and hedge funds who marginally profited by driving away pricing inefficiencies through the application of high-tech statistical models.

Perhaps most importantly, an entire government agency, the Office of Federal Housing Enterprise Oversight [OFHEO] existed for evaluating the capital adequacy of the large quasi-governmental mortgage insurance companies; Fannie Mae and Freddie Mac. OFHEO carefully collected housing and mortgage data from these agencies and constructed indexes of home price appreciation, using well-tested, academically validated

\footnotetext{
${ }^{26}$ An important exception to this is the triple A standard for money market funds and the investment grade standard for regulated institutional portfolios such as banks and insurance companies.
} 
econometric methodologies, in order to continuously assess the relationship between the value of the underlying collateral - the housing stock - and the agencies' liabilities. ${ }^{27}$

In all of these sectors, the explosion of data, increasingly sophisticated and well-tested models and the widespread employment of well-trained professional analysts, and the genuine commitment of regulatory entities in banking and mortgage insurance provided reasonable grounds for comfort that any potential future crisis in the financial markets and institutions would be detectable and quantifiable.

The further irony is that the innovations in securitization in the early 2000's were likewise deemed revolutionary. Although the instruments were complex, the concept was simple. Institutions became risk packagers who creatively parsed risks and sold them to the entities most suited to hold them. For example, if the residual tranche of a collateralized mortgage obligation was inappropriate for a fixed income mutual fund, it might be perfect for a speculative hedge fund seeking high return and willing to take high risks. The safer tranches that remained might better match the risk appetite of the mutual fund. Market observers generally believed that securitization, which had created a liquid, global, efficient market for risk, rendered our financial system robust to any single negative shock. ${ }^{28}$ After all, if mortgages in a single city went bad, this loss would be diffused broadly among the world's investors rather than being concentrated in a single, possibly fragile institution. And still better, those harmed would be those who were best prepared for the loss.

Parallel to the innovations in the asset-backed securitization market were remarkable strides in tools for mitigating corporate default risk. Credit default swaps were a new form of financial contract in the early 2000s and they became a major mechanism for measuring and allocating the risk of corporate bond defaults. This revolution in the monetization of risk extended equally to the commodities markets - particularly to energy futures - where over-the-counter trading, while not new, grew dramatically.

Market participants and observers in the early part of the decade were not naïve enough to believe that the twin revolutions in risk management and securitization had eliminated risk, or even reduced it much. They did mostly believe that the new quantification and commodification of risk allowed for a more efficient allocation of it, and a new, more precise awareness of its consequences. Again, these beliefs seem in retrospect to have been pitifully optimistic. The point germane to the evidence in this paper is that the foundation of these beliefs rested, in part, on quantification and modeling - the collection and analysis of data -- and forecasting of the range of future trends.

One general lesson for future risk management to take from the analysis in this paper is that unconditional forecasts made on conditional data can go very wrong. In the case of the subprime crisis, data were generated under institutional conditions such as a liquid markets for securitized mortgage debt and for housing. Failure of these conditions after 2006 represented an important (and difficult to model) regime-switch.

\footnotetext{
${ }^{27}$ Cf. Calhoun (1996)

${ }^{28}$ Some readers will not count themselves among these market observers. There were certainly contrarian views.
} 


\section{References}

Avery, Robert B., Brevoort, Kenneth P. and Canner, Glenn B., "The 2006 HMDA Data" Federal Reserve Bulletin, vol. 93 (December 2007), pp. A73-A109.

Bailey, M., R. Muth and H. Nourse, 1963, “A Regression Method for Real Estate Price Index Construction,” J. Amer. Statist. Assoc. 58 pp. 933-942.

Brunnermeier, Markus and Christian Julliard, 2008, "Money Illusion and Housing Frenzies," Review of Financial Studies, 21(1), 135-180.

Calem, Paul S., Gillen, Kevin and Wachter, Susan M., 2003, “The Neighborhood Distribution of Subprime Mortgage Lending," U of Penn, Inst for Law \& Econ Research Paper 03-39.

Calhoun, Charles A., 1996, "OFHEO House Price Indexes: HPI Technical Description," Office of Federal Housing Enterprise Oversight.

Caplin, A, S Chan, C Freeman, J Tracy, 1999, "Household Asset Portfolios and the Reform of the Housing Finance Market," TIAA-CREF Research Dialogues.

Capozza, Dennis R., Dick Kazarian, Thomas A. Thomson, 1997, "Mortgage Default in Local Markets," Real Estate Economics, 25 (4), pp. 631-655.

Case and R. Shiller, 1987, Prices of Single-Family Homes since 1970: New Indexes for Four Cities. New England Economic Review Sep/Oct 87 (1987), pp. 45-56.

Case, Karl E., and Robert J. Shiller, 1988, "The Behavior of Home Buyers in Boom and Post-Boom Markets," New England Economic Review pp. 2-46, November/December. 36.

Case, Karl E., and Robert J. Shiller, 1989, “The Efficiency of the Market for SingleFamily Homes," American Economic Review 79(1):125-37.

Case, Karl E. and R. Shiller, 1990, Forecasting Prices and Excess Returns in the Housing Market, AREUEA J. 18, pp. 253-273.

Case Karl E. and Robert J. Shiller, 2003, "Is There a Bubble in the Housing Market?," Brookings Papers on Economic Activity, Economic Studies Program, The Brookings Institution, vol. 34(2), pages 299-362.

Clayton, Jim, Norman Miller, and Liang Peng, 2008, "Price-Volume Correlation in the Housing Market: Causality and Co-movement," Journal of Real Estate Finance and Economics, forthcoming

Crews Cutts, Amy, and Robert A. Van Order, 2005, "On the economics of subprime lending, "The Journal of Real Estate Finance and Economics 30, 167-196.

Demyanyk, Yuliya and Van Hemert, Otto, 2008," Understanding the Subprime Mortgage Crisis, New York University Working Paper. 
Deng, Y., Quigley, J., and Van Order, J., 2000. "Mortgage Terminations, Heterogeneity, and the Exercise of Mortgage Options." Econometrica, 68(2): 275-308.

Dhar, Ravi and Ning Zhu, 2006, "Up Close and Personal: Investor Sophistication and the Disposition Effect," Management Science, Vol. 52, No. 5, May 2006, pp. 726-740.

Doms, Mark, Furlong, Fred and Krainer, John, 2007, "Subprime Mortgage Delinquency Rates" Federal Reserve Bank of San Francisco Working Paper 2007-33

Downing, Chris , Richard Stanton and Nancy Wallace, 2005, “An Empirical Test of a Two-Factor Mortgage Valuation Model: How Much Do House Prices Matter?" Real Estate Economics, Volume 33 Issue 4, Pages 681 - 710.

Gabriel, Stuart and Stuart Rosenthal, 2007, "Secondary Markets, Risk, and Access to Credit: Evidence from the Mortgage Market," Working Paper, Syracuse University.

Geltner, David, 1997, "Bias and Precision of Estimates of Housing Investment Risk Based n Repeat-Sales Indexes: A Simulation Analysis," Journal of Real Estate Finance and Economics, 14: 155-171.

Glaeser, Edward L., Gyourko, Joseph E. and Saks, Raven E., 2005, "Why Have Housing Prices Gone Up?" The American Economic Review, Volume 95, Number 2, May , pp. 329-333.

Goetzmann, William N., 1992, The Accuracy of Real Estate Indexes: Repeat Sales Estimators. Journal of Real Estate Finance and Economics 5, pp. 5-53.

Goetzmann, William N. and Liang Peng, 2006, "Estimating House Price Indexes in the Presence of Seller Reservation Prices, The Review of Economics and Statistics, 88(1): 100-112.

Goetzmann, William N. and Matthew I. Spiegel, 2002, "Policy Implications of Portfolio Choice in Underserved Mortgage Markets," in Low-Income Homeownership: Examining the Unexamined Goal by Nicolas P. Retsinas and Eric S. Belsky.

Goetzmann, William N. and Eduardas Valaitis, 2006, "Simulating Real Estate in the Investment Portfolio: Model Uncertainty and Inflation Hedging," Yale ICF Working Paper No. 06-04

Keys, Benjamin J., Mukherjee, Tanmoy K., Seru, Amit and Vig, Vikrant, 2008, "Did Securitization Lead to Lax Screening? Evidence from Subprime Loans," SSRN Working Paper.

Lin, Zhenguo and Kerry D. Vandell, 2007, "Illiquidity and Pricing Biases in the Real Estate Market," Real Estate Economics, Volume 35, Issue 3, Pages 291-330.

Mian, Atif, and Amir Sufi, 2008, "The Consequences of Mortgage Credit Expansion: Evidence from the 2007 Mortgage Default Crisis," working paper, University of Chicago. 
Pennington-Cross, Anthony, and Souphala Chomsisengphet, 2007, "Subprime Refinancing: Equity Extraction and Mortgage Termination," Real Estate Economics 35, 233-263.

Rajan, Uday, Amit Seru, and Vikrant Vig, 2008, “ The Failure of Models That Predict Failure: Distance, Incentives and Defaults,” Working paper

Shiller, Robert, ,1991, Arithmetic Repeat Sales Price Estimators. Journal of Housing Economics 1, pp. 110-126.

Shumway, Robert H., and David Stoffer, 2006, Series Analysis and Its Applications: With $R$ Examples, Springer Texts in Statistics.

Wachter, Susan M., Russo, Karl and Hershaff, Jonathan E., 2005, "Subprime Lending: Neighborhood Patterns Over Time in US Cities." U of Penn, Inst for Law \& Econ . 
Figure 1

Figure 1: Case-Shiller Monthly Repeat-Sales Indices for 20 Major U.S. Housing Markets

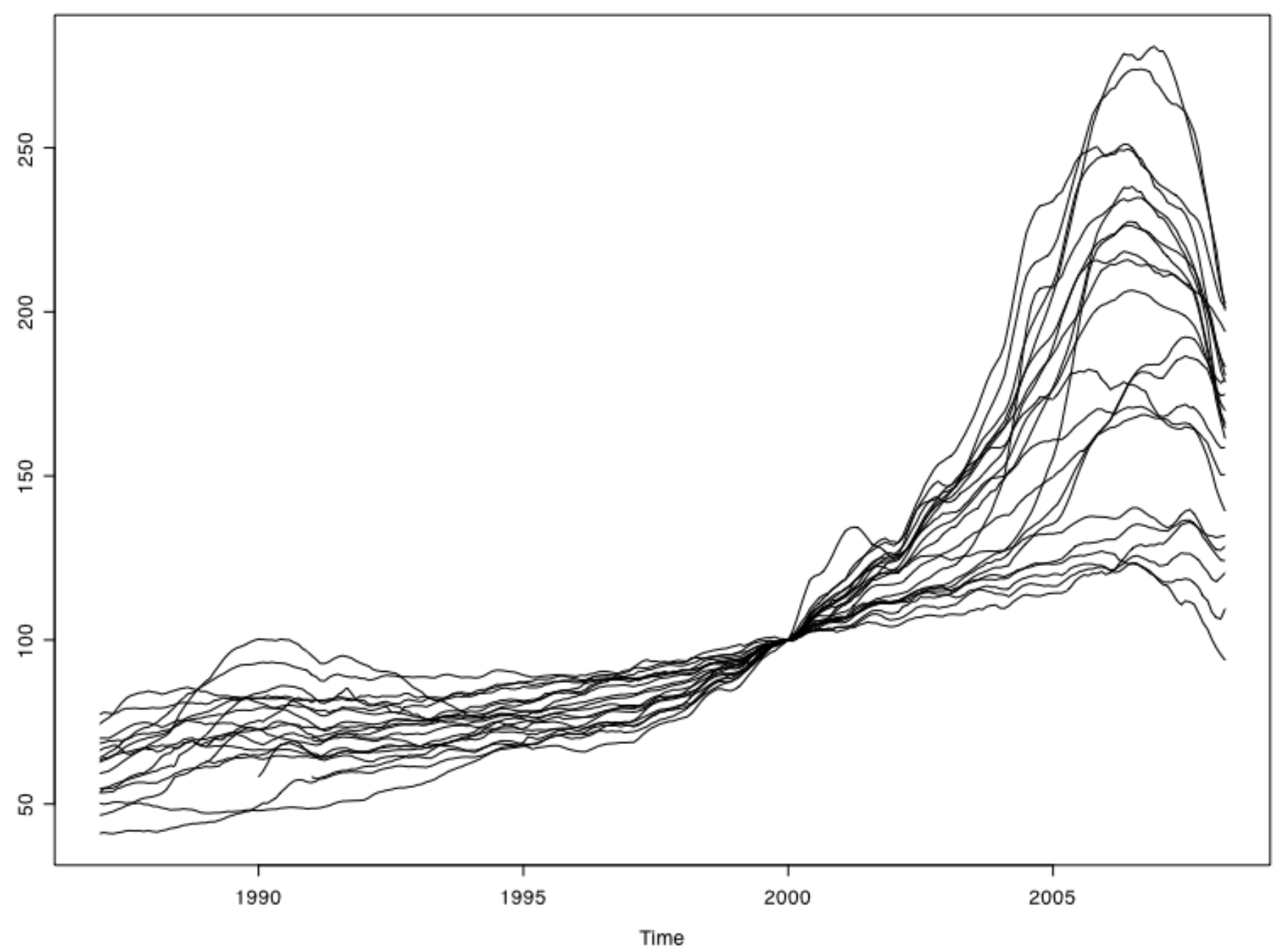


Figure 2

Figure 2: K-Means Clusters of MSAs: 1980-2005

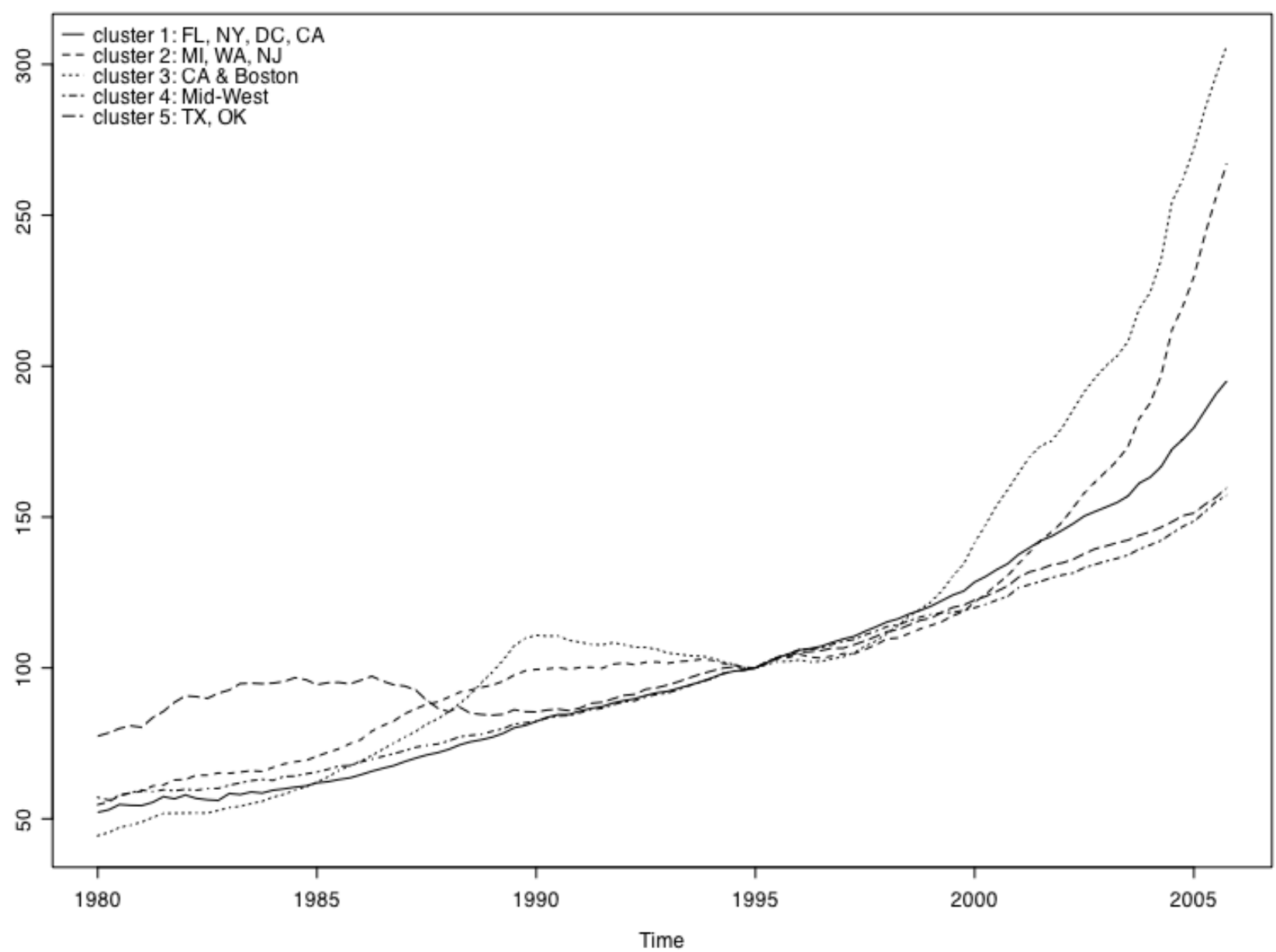


Figure 3

Anualized Mean and Standard Deviation of Case-Shiller Indices 1987-2005

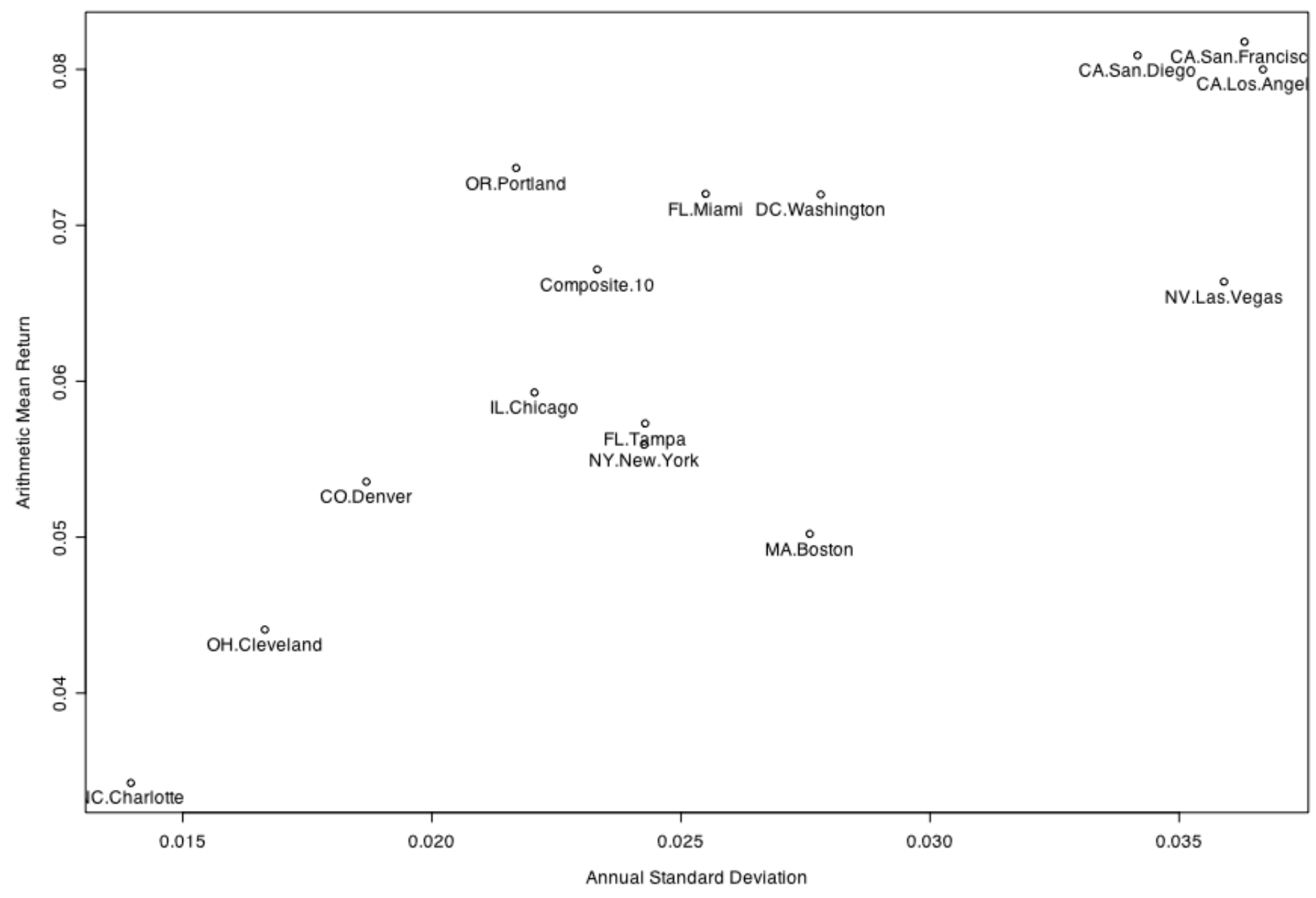


Figure 4

Anualized Mean and Standard Deviation of OFHEO Indices 1987-2005

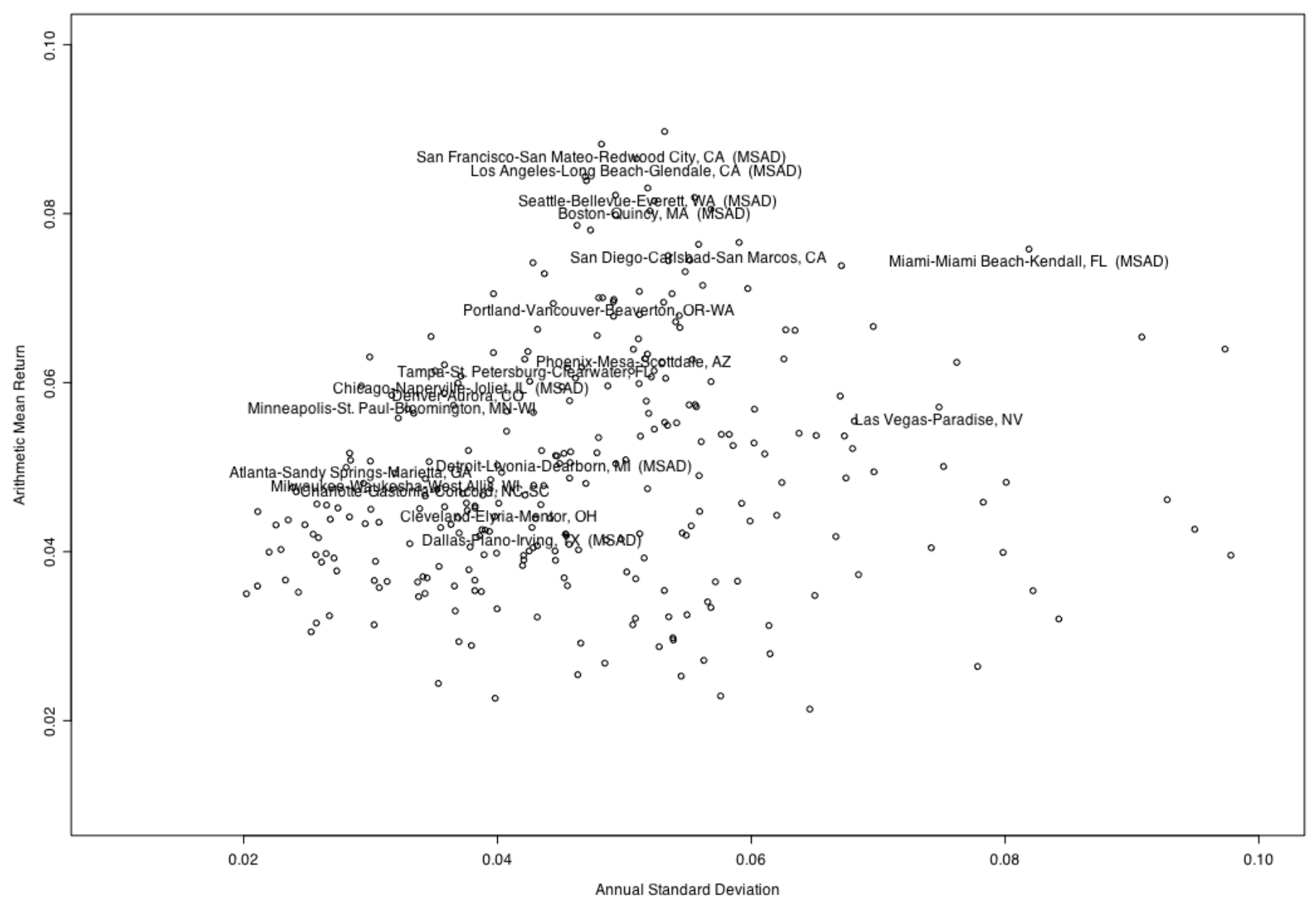


$1-1-10$

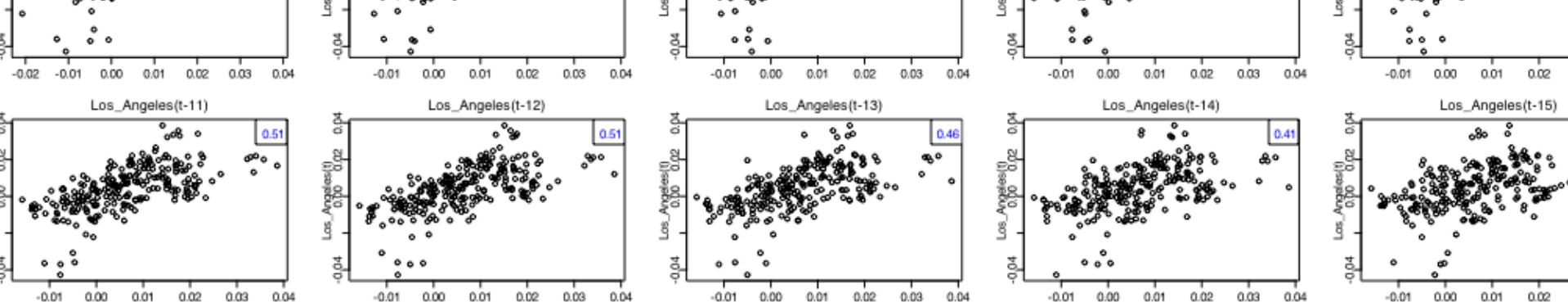

$-1$ 
Figure 6
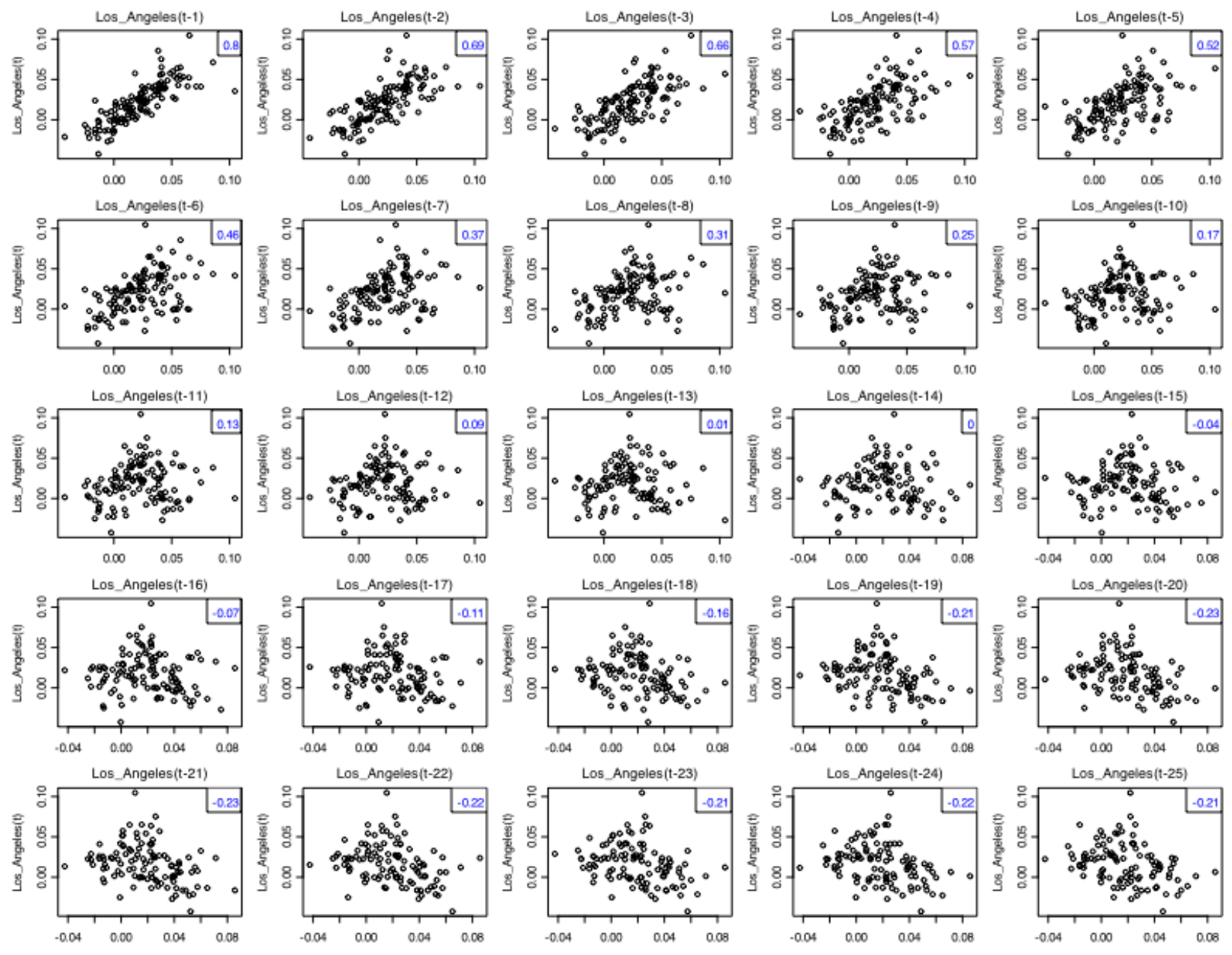
Figure 7
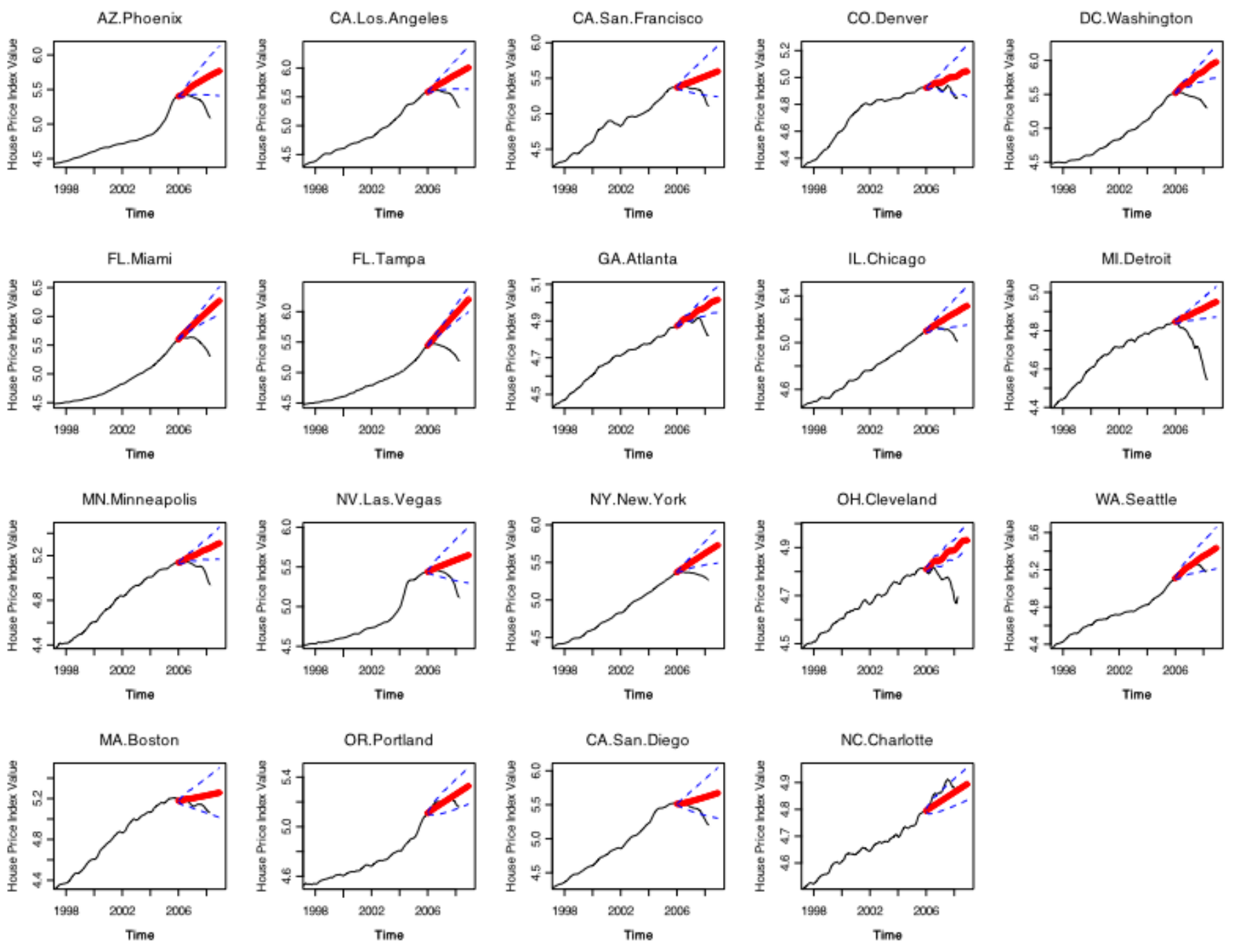
Figure 8
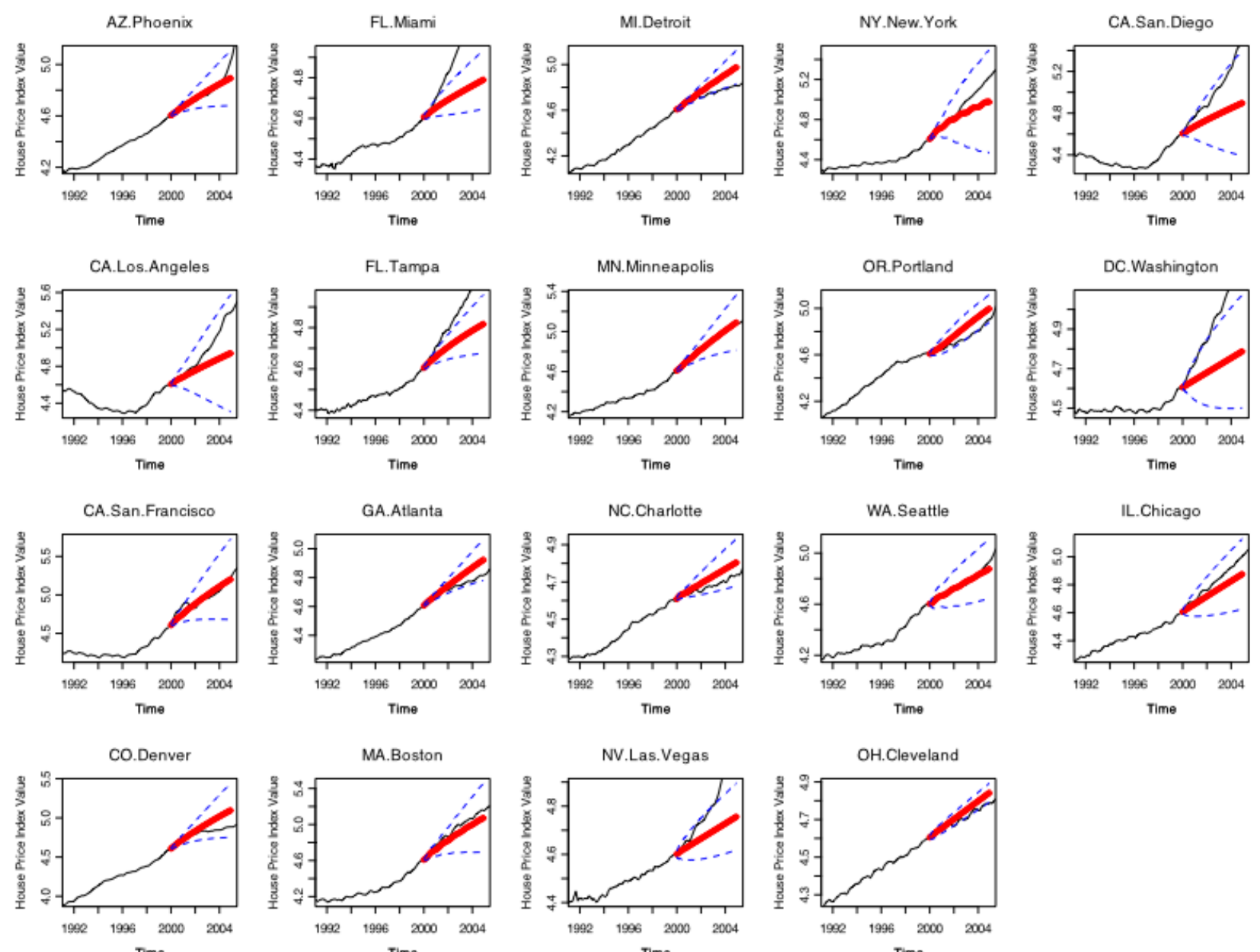
Figure 9
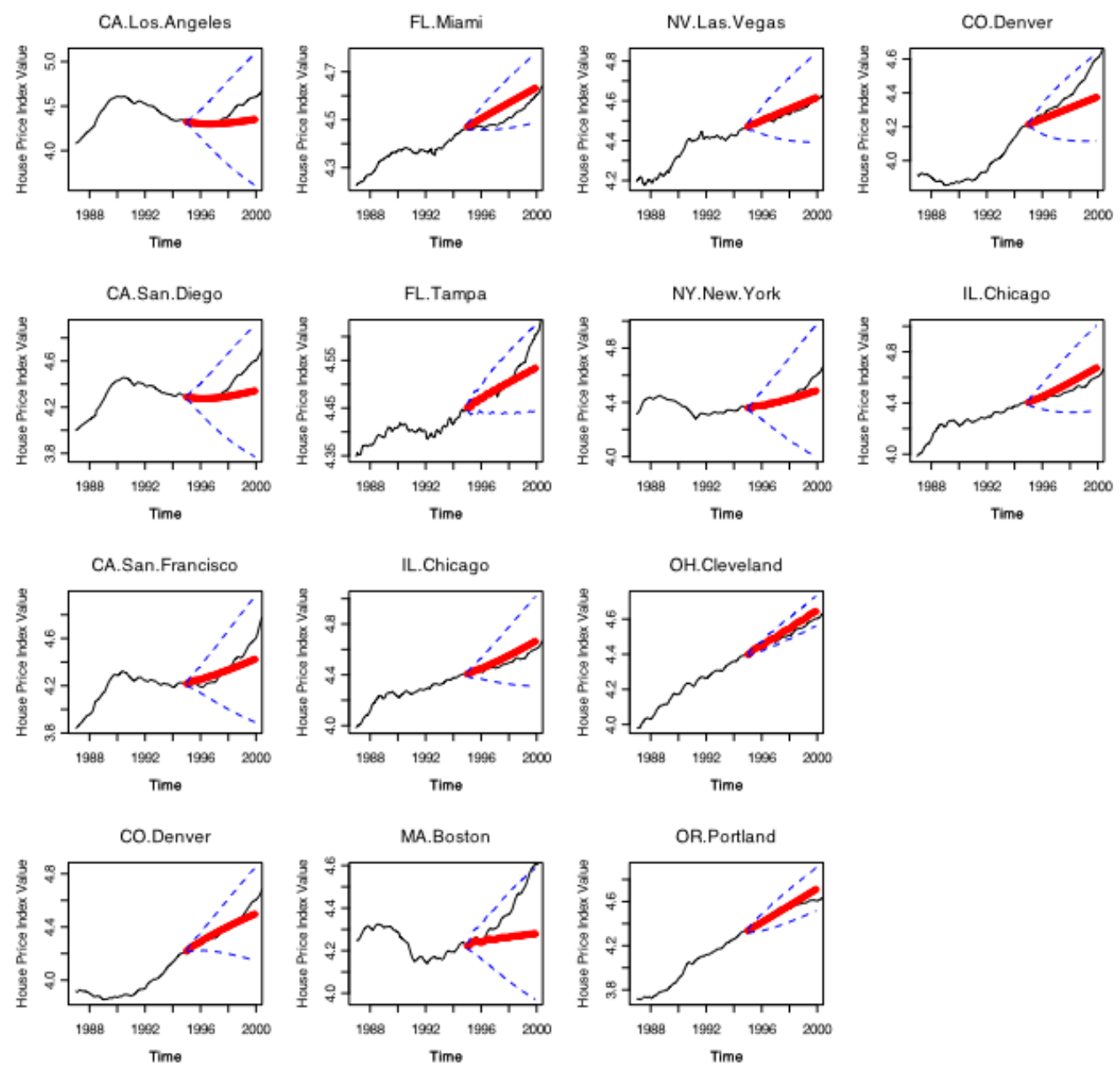
Figure 10

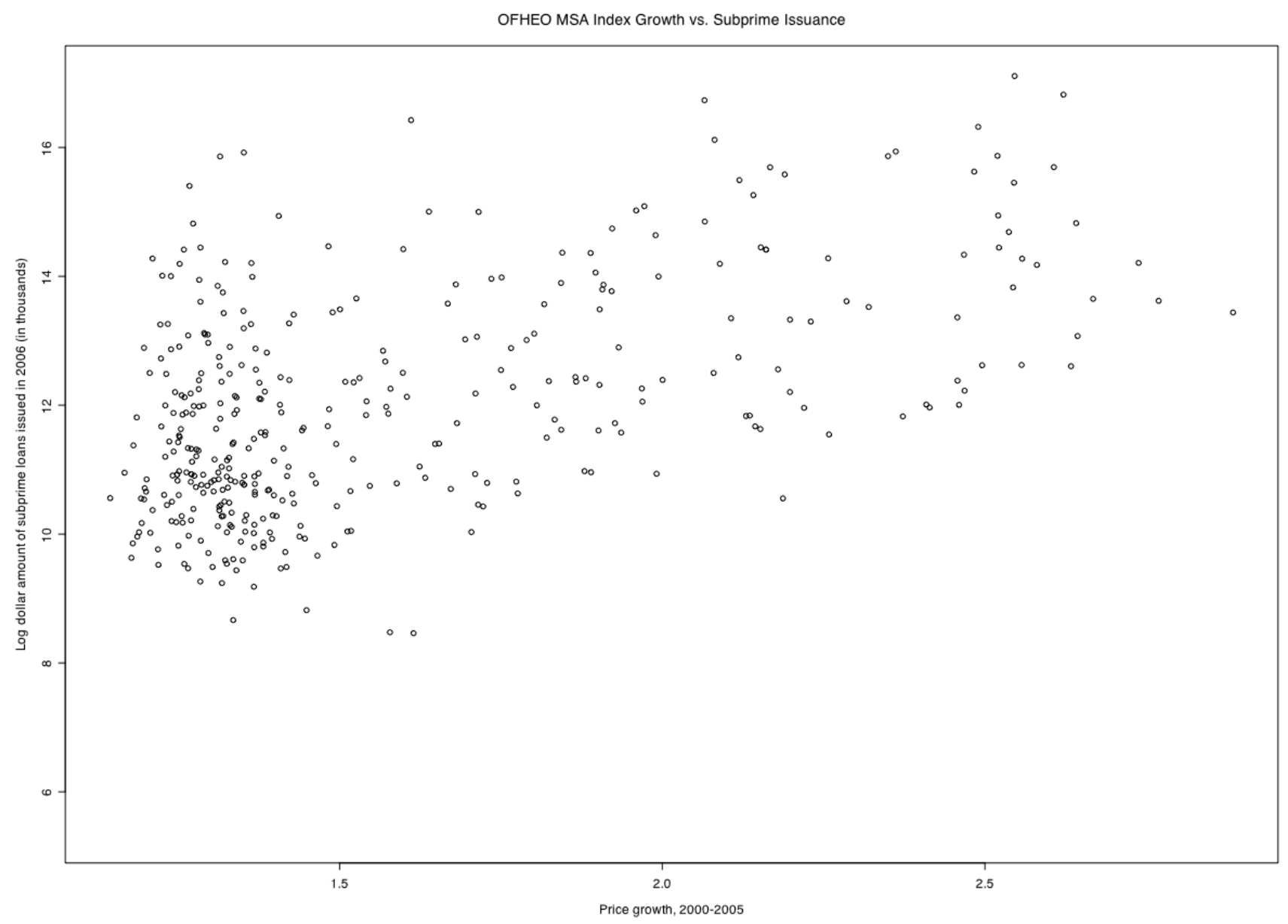


Figure 11

Prime vs. Sub-Prime Income Spread vs. Price Appreciation 2000-2005

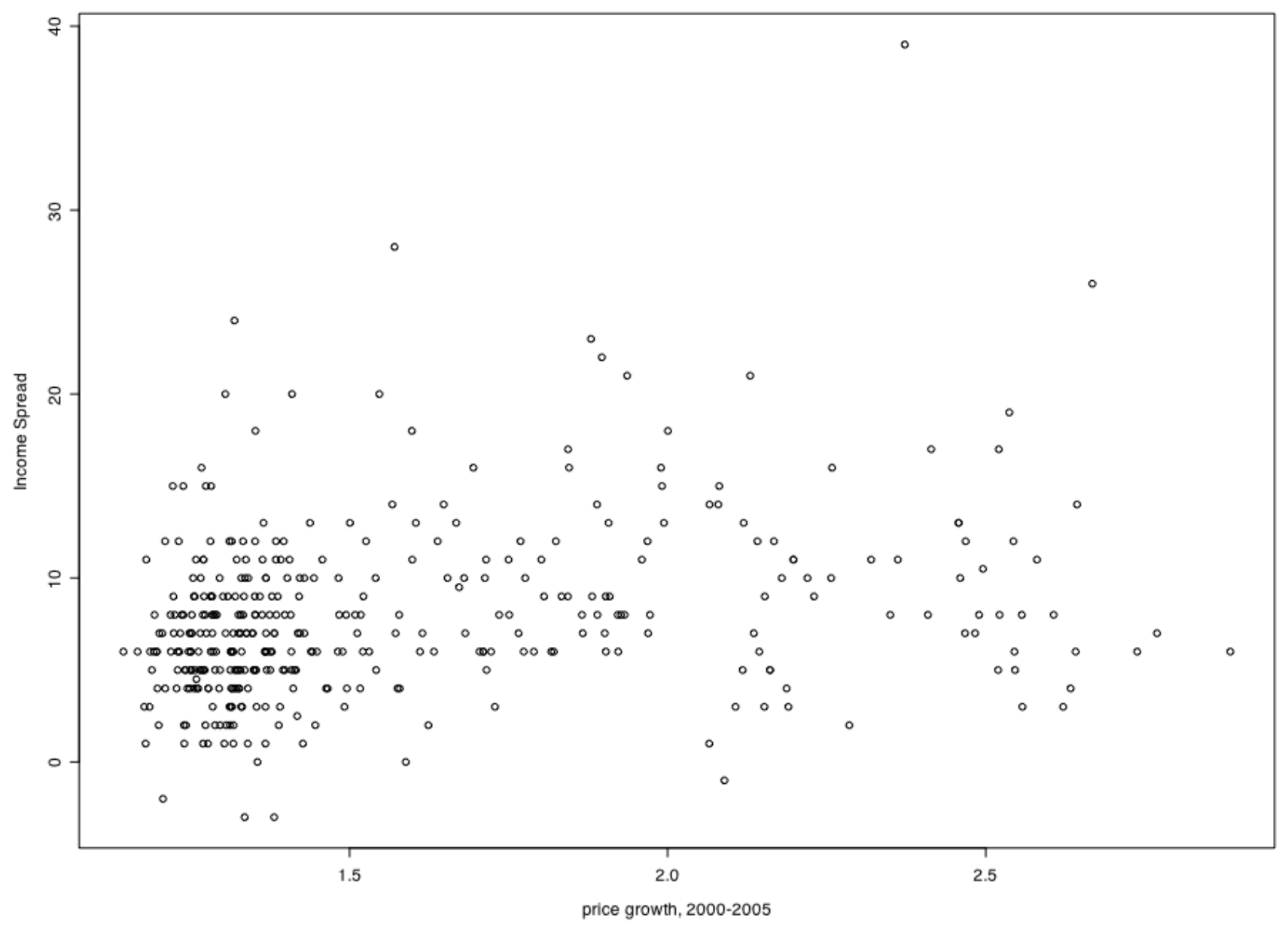


Table 1. Demand for prime mortgages and past price changes

This table reports cross-sectional MSA level linear regressions regarding the determinants of the demand for prime mortgages in 2006. The demand is measured with the number of mortgage applications (in log) and the volume of applications (in log of \$ thousands). Explanatory variables for each MSA are: [past price change (log)] the log of the ratio of the OFEHO house price index in 1999:4 to the index in 2005:4, [population $(\log )$ ] the log of the population of the MSA from the 2006 American Community Survey dataset [ACS], [unemployment\% (log)] the log of the MSA unemployment rate in 2006 from Bureau of Labor Statistics (BLS), [65 and above\% (log)] the log of the percentage of the population over 65 from ACS, [high school\% $(\log )]$ the log of the percentage of the population with a high school degree from ACS, and [income per capita (log)] the log of income per capita (in \$ thousands) from ACS. Heteroskedasticity-consistent standard deviations are reported in parentheses. $* * *$ denotes significance at the $1 \%$ level, $* *$ at the $5 \%$ level, and $*$ at $10 \%$ level.

\begin{tabular}{|c|c|c|c|c|}
\hline Explanatory variables & \multicolumn{4}{|c|}{ Dependant variables } \\
\hline & \multicolumn{2}{|c|}{ Loans (in log) } & \multicolumn{2}{|c|}{ Volume (in log) } \\
\hline Past price change (log) & $\begin{array}{c}* * * 1.752 \\
(0.269)\end{array}$ & $\begin{array}{c}* * * 0.488 \\
(0.087)\end{array}$ & $\begin{array}{c}* * * 3.134 \\
(0.289)\end{array}$ & $\begin{array}{c}* * * 1.606 \\
(0.096)\end{array}$ \\
\hline Population (log) & & $\begin{array}{c}* * * 1.078 \\
(0.021)\end{array}$ & & $\begin{array}{c}* * * 1.071 \\
(0.024)\end{array}$ \\
\hline Unemployment\% (log) & & $\begin{array}{c}* * *-0.240 \\
(0.060)\end{array}$ & & $\begin{array}{c}* * *-0.233 \\
(0.072)\end{array}$ \\
\hline 65 and above\% (log) & & $\begin{array}{c}* * *-0.318 \\
(0.093)\end{array}$ & & $\begin{array}{c}* * *-0.651 \\
(0.108)\end{array}$ \\
\hline High school\% (log) & & $\begin{array}{c}0.199 \\
(0.316)\end{array}$ & & $\begin{array}{c}-0.261 \\
(0.392)\end{array}$ \\
\hline Income per capita (log) & & $\begin{array}{c}0.103 \\
(0.175)\end{array}$ & & $\begin{array}{c}* * * 1.023 \\
(0.210)\end{array}$ \\
\hline Sample size & 376 & 344 & 376 & 344 \\
\hline Adjusted R2 & 0.11 & 0.93 & 0.25 & 0.93 \\
\hline
\end{tabular}


Table 2. Demand for subprime mortgages and past price changes

This table reports cross-sectional MSA level linear regressions regarding the determinants of the demand for subprime mortgages in 2006. The demand is measured with the number of mortgage applications (in log) and the volume of applications (in log of \$ thousands). Explanatory variables for each MSA are: [past price change (log)] the log of the ratio of the OFEHO house price index in 1999:4 to the index in 2005:4, [population (log)] the log of the population of the MSA from the 2006 American Community Survey dataset [ACS], [unemployment\% (log)] the log of the MSA unemployment rate in 2006 from Bureau of Labor Statistics (BLS), [65 and above\% (log)] the log of the percentage of the population over 65 from ACS, [high school\% (log)] the log of the percentage of the population with a high school degree from ACS, [income per capita (log)] the log of income per capita (in \$ thousands) from ACS, and [Prime applications (log)] the number (for loan regressions) or volume (for volume regression) of prime mortgage applications. Heteroskedasticity-consistent standard deviations are reported in parentheses. $* * *$ denotes significance at the $1 \%$ level, $* *$ at the $5 \%$ level, and $*$ at $10 \%$ level.

\begin{tabular}{|c|c|c|c|c|c|c|}
\hline Explanatory variables & \multicolumn{6}{|c|}{ Dependant variables } \\
\hline & \multicolumn{3}{|c|}{ Loans (in log) } & \multicolumn{3}{|c|}{ Volume (in log) } \\
\hline Past price change (log) & $\begin{array}{c}* * * 2.624 \\
(0.318)\end{array}$ & $\begin{array}{c}* * * 1.049 \\
(0.129)\end{array}$ & $\begin{array}{c}* * * 0.558 \\
(0.104)\end{array}$ & $\begin{array}{c}* * * 3.957 \\
(0.331)\end{array}$ & $\begin{array}{c}* * * 2.175 \\
(0.140)\end{array}$ & $\begin{array}{c}* * * 0.573 \\
(0.150)\end{array}$ \\
\hline Population (log) & & $\begin{array}{c}* * * 1.321 \\
(0.032)\end{array}$ & $\begin{array}{c}* * * 0.238 \\
(0.091)\end{array}$ & & $\begin{array}{c}* * * 1.316 \\
(0.034)\end{array}$ & $\begin{array}{c}* * * 0.248 \\
(0.081)\end{array}$ \\
\hline Unemployment\% (log) & & $\begin{array}{l}* * 0.200 \\
(0.090)\end{array}$ & $\begin{array}{c}* * * 0.441 \\
(0.080)\end{array}$ & & $\begin{array}{l}* 0.203 \\
(0.103)\end{array}$ & $\begin{array}{c}* * * 0.435 \\
(0.081)\end{array}$ \\
\hline 65 and above\% (log) & & $\begin{array}{c}-0.015 \\
(0.147)\end{array}$ & $\begin{array}{c}* * * 0.304 \\
(0.098)\end{array}$ & & $\begin{array}{c}* *-0.334 \\
(0.160)\end{array}$ & $\begin{array}{c}* * * 0.315 \\
(0.108)\end{array}$ \\
\hline High school\% (log) & & $\begin{array}{c}* * *-1.654 \\
(0.519)\end{array}$ & $\begin{array}{c}* * *-1.854 \\
(0.418)\end{array}$ & & $\begin{array}{c}* * *-2.155 \\
(0.588)\end{array}$ & $\begin{array}{c}* * *-1.895 \\
(0.415)\end{array}$ \\
\hline Income per capita (log) & & $\begin{array}{c}-0.194 \\
(0.261)\end{array}$ & $\begin{array}{l}-0.297 \\
(0.201)\end{array}$ & & $\begin{array}{c}0.493 \\
(0.308)\end{array}$ & $\begin{array}{c}* *-0.527 \\
(0.221)\end{array}$ \\
\hline Prime applications (log) & & & $\begin{array}{c}* * * 1.005 \\
(0.081)\end{array}$ & & & $\begin{array}{c}* * * 0.996 \\
(0.073)\end{array}$ \\
\hline Sample size & 376 & 344 & 344 & 376 & 344 & 344 \\
\hline Adjusted R2 & 0.16 & 0.88 & 0.93 & 0.28 & 0.89 & 0.94 \\
\hline
\end{tabular}


Table 3. Application loan to income ratios and past price changes

This table reports cross-sectional MSA level linear regressions regarding the loan to income ratio of the prime and subprime mortgage applications in 2006. The dependant variable is the MSA average ratio (in log) of loan size to applicant gross annual income. Explanatory variables for each MSA are: [past price change (log)] the log of the ratio of the OFEHO house price index in 1999:4 to the index in 2005:4, [population $(\mathrm{log})$ ] the log of the population of the MSA from the 2006 American Community Survey dataset $[\mathrm{ACS}$ ], [unemployment\% (log)] the log of the MSA unemployment rate in 2006 from Bureau of Labor Statistics (BLS), [65 and above\% (log)] the log of the percentage of the population over 65 from ACS, [high school\% (log)] the log of the percentage of the population with a high school degree from ACS, [income per capita (log)] the log of income per capita (in \$ thousands) from ACS, and [Price income ratio (log)] the log of the ratio of median existing single family home price to median household income from economy.com. Heteroskedasticity-consistent standard deviations are reported in parentheses. *** denotes significance at the $1 \%$ level, $* *$ at the $5 \%$ level, and $*$ at $10 \%$ level.

\begin{tabular}{|c|c|c|c|c|c|c|}
\hline Explanatory variables & \multicolumn{6}{|c|}{ Mortgage types } \\
\hline & \multicolumn{3}{|c|}{ Prime } & \multicolumn{3}{|c|}{ Subprime } \\
\hline Past price change $(\log )$ & $\begin{array}{c}* * * 0.329 \\
(0.025)\end{array}$ & $\begin{array}{c}* * * 0.325 \\
(0.025)\end{array}$ & $\begin{array}{c}* * * 0.304 \\
(0.028)\end{array}$ & $\begin{array}{c}* * * 0.219 \\
(0.020)\end{array}$ & $\begin{array}{c}* * * 0.209 \\
(0.021)\end{array}$ & $\begin{array}{c}* * * 0.137 \\
(0.027)\end{array}$ \\
\hline Population (log) & & & $\begin{array}{c}* *-0.015 \\
(0.008)\end{array}$ & & & $\begin{array}{c}0.003 \\
(0.007)\end{array}$ \\
\hline Unemployment\% (log) & & & $\begin{array}{c}* * * 0.067 \\
(0.022)\end{array}$ & & & $\begin{array}{r}* * * 0.065 \\
(0.023)\end{array}$ \\
\hline 65 and above\% (log) & & & $\begin{array}{c}* * *-0.091 \\
(0.030)\end{array}$ & & & $\begin{array}{c}0.029 \\
(0.027)\end{array}$ \\
\hline High school\% (log) & & & $\begin{array}{c}* * 0.282 \\
(0.135)\end{array}$ & & & $\begin{array}{c}-0.167 \\
(0.131)\end{array}$ \\
\hline Income per capita (log) & & & $\begin{array}{l}* * 0.153 \\
(0.064)\end{array}$ & & & $\begin{array}{c}* * * 0.180 \\
(0.059)\end{array}$ \\
\hline Price income ratio $(\mathrm{log})$ & & $\begin{array}{c}0.020 \\
(0.014)\end{array}$ & $\begin{array}{c}0.004 \\
(0.015)\end{array}$ & & $\begin{array}{c}* * 0.029 \\
(0.014)\end{array}$ & $\begin{array}{c}0.013 \\
(0.015)\end{array}$ \\
\hline Sample size & 376 & 368 & 336 & 376 & 368 & 336 \\
\hline Adjusted R2 & 0.32 & 0.32 & 0.37 & 0.17 & 0.18 & 0.18 \\
\hline
\end{tabular}


Table 4. Application loan to value ratio and past price changes

This table reports cross-sectional MSA level linear regressions regarding the loan to value ratio of the prime and subprime mortgage applications in 2006. The dependant variable is the MSA average ratio (in log) of loan size to home value of mortgage applications, which is inferred from two ratios: the average loan to value ratio of mortgage approvals from Loan Performance and the ratio of the average size of mortgage applications to the average size of mortgage approvals from HMDA. Explanatory variables for each MSA are: [past price change (log)] the log of the ratio of the OFEHO house price index in 1999:4 to the index in 2005:4, [population (log)] the log of the population of the MSA from the 2006 American Community Survey dataset [ACS], [unemployment\% (log)] the log of the MSA unemployment rate in 2006 from Bureau of Labor Statistics (BLS), [65 and above\% (log)] the log of the percentage of the population over 65 from ACS, [high school\% (log)] the log of the percentage of the population with a high school degree from ACS, [income per capita (log)] the log of income per capita (in \$ thousands) from ACS, and [Price income ratio (log)] the log of the ratio of median existing single family home price to median household income from economy.com. Heteroskedasticity-consistent standard deviations are reported in parentheses. *** denotes significance at the $1 \%$ level, $* *$ at the $5 \%$ level, and $*$ at $10 \%$ level.

\begin{tabular}{|c|c|c|c|c|c|c|}
\hline \multirow{3}{*}{$\begin{array}{l}\text { Explanatory variables } \\
\text { Past price change (log) }\end{array}$} & \multicolumn{6}{|c|}{ Mortgage types } \\
\hline & \multicolumn{3}{|c|}{ Prime } & \multicolumn{3}{|c|}{ Subprime } \\
\hline & $\begin{array}{c}* * *-0.118 \\
(0.010)\end{array}$ & $\begin{array}{c}* * *-0.116 \\
(0.011)\end{array}$ & $\begin{array}{c}* * *-0.080 \\
(0.012)\end{array}$ & $\begin{array}{c}* * *-0.175 \\
(0.012)\end{array}$ & $\begin{array}{c}* * *-0.183 \\
(0.013)\end{array}$ & $\begin{array}{c}* * *-0.196 \\
(0.017)\end{array}$ \\
\hline Population (log) & & & $\begin{array}{c}-0.002 \\
(0.003)\end{array}$ & & & $\begin{array}{c}0.003 \\
(0.005)\end{array}$ \\
\hline Unemployment\% (log) & & & $\begin{array}{c}0.003 \\
(0.007)\end{array}$ & & & $\begin{array}{c}* * 0.025 \\
(0.012)\end{array}$ \\
\hline 65 and above\% (log) & & & $\begin{array}{c}-0.013 \\
(0.011)\end{array}$ & & & $\begin{array}{c}* * 0.059 \\
(0.023)\end{array}$ \\
\hline High school\% (log) & & & $\begin{array}{c}* * 0.103 \\
(0.052)\end{array}$ & & & $\begin{array}{c}0.072 \\
(0.069)\end{array}$ \\
\hline Income per capita (log) & & & $\begin{array}{c}* * *-0.125 \\
(0.024)\end{array}$ & & & $\begin{array}{c}0.030 \\
(0.031)\end{array}$ \\
\hline Price income ratio $(\mathrm{log})$ & & $\begin{array}{c}* *-0.013 \\
(0.006)\end{array}$ & $\begin{array}{l}*-0.010 \\
(0.005)\end{array}$ & & $\begin{array}{c}* * 0.021 \\
(0.009)\end{array}$ & $\begin{array}{c}* * 0.018 \\
(0.008)\end{array}$ \\
\hline Sample size & 347 & 339 & 336 & 347 & 339 & 336 \\
\hline Adjusted R2 & 0.28 & 0.30 & 0.41 & 0.25 & 0.26 & 0.29 \\
\hline
\end{tabular}


Table 5. Application home value to income ratio and past price changes

This table reports cross-sectional MSA level linear regressions regarding the home value to income ratio of the prime and subprime mortgage applications in 2006. The dependant variable is the MSA average ratio (in log) of home value to applicant gross annual income, which is inferred from two ratios: the average loan to value ratio (in table 4) and the average loan to income ratio of mortgage applications. Explanatory variables for each MSA are: [past price change (log)] the log of the ratio of the OFEHO house price index in 1999:4 to the index in 2005:4, [population (log)] the log of the population of the MSA from the 2006 American Community Survey dataset [ACS], [unemployment\% (log)] the log of the MSA unemployment rate in 2006 from Bureau of Labor Statistics (BLS), [65 and above\% (log)] the log of the percentage of the population over 65 from ACS, [high school\% $(\log )]$ the log of the percentage of the population with a high school degree from ACS, [income per capita (log)] the log of income per capita (in \$ thousands) from ACS, and [Price income ratio (log)] the log of the ratio of median existing single family home price to median household income from economy.com. Heteroskedasticity-consistent standard deviations are reported in parentheses. $* * *$ denotes significance at the $1 \%$ level, $* *$ at the $5 \%$ level, and $*$ at $10 \%$ level.

\begin{tabular}{|c|c|c|c|c|c|c|}
\hline Explanatory variables & \multicolumn{6}{|c|}{ Mortgage types } \\
\hline & \multicolumn{3}{|c|}{ Prime } & \multicolumn{3}{|c|}{ Subprime } \\
\hline Past price change (log) & $\begin{array}{c}* * * 0.434 \\
(0.031)\end{array}$ & $\begin{array}{c}* * * 0.431 \\
(0.032)\end{array}$ & $\begin{array}{c}* * * 0.384 \\
(0.033)\end{array}$ & $\begin{array}{c}* * * 0.375 \\
(0.025)\end{array}$ & $\begin{array}{c}* * * 0.376 \\
(0.026)\end{array}$ & $\begin{array}{c}* * * 0.333 \\
(0.030)\end{array}$ \\
\hline Population (log) & & & $\begin{array}{l}-0.013 \\
(0.008)\end{array}$ & & & $\begin{array}{c}0.000 \\
(0.009)\end{array}$ \\
\hline Unemployment\% (log) & & & $\begin{array}{c}* * * 0.064 \\
(0.023)\end{array}$ & & & $\begin{array}{c}0.039 \\
(0.025)\end{array}$ \\
\hline 65 and above\% (log) & & & $\begin{array}{c}* *-0.078 \\
(0.031)\end{array}$ & & & $\begin{array}{c}-0.030 \\
(0.037)\end{array}$ \\
\hline High school\% (log) & & & $\begin{array}{c}0.179 \\
(0.153)\end{array}$ & & & $\begin{array}{l}*-0.239 \\
(0.144)\end{array}$ \\
\hline Income per capita (log) & & & $\begin{array}{c}* * * 0.278 \\
(0.073)\end{array}$ & & & $\begin{array}{c}* * 0.150 \\
(0.068)\end{array}$ \\
\hline Price income ratio (log) & & $\begin{array}{c}0.022 \\
(0.018)\end{array}$ & $\begin{array}{c}0.014 \\
(0.017)\end{array}$ & & $\begin{array}{c}-0.000 \\
(0.018)\end{array}$ & $\begin{array}{c}-0.004 \\
(0.018)\end{array}$ \\
\hline Sample size & 347 & 339 & 336 & 347 & 339 & 336 \\
\hline Adjusted R2 & 0.39 & 0.39 & 0.48 & 0.32 & 0.32 & 0.33 \\
\hline
\end{tabular}


Table 6. Approvals of prime mortgages and past price changes

This table reports cross-sectional MSA level linear regressions regarding the determinants of the approvals of prime mortgages in 2006. The approvals are measured with the number of mortgage approved (in log) and the volume of mortgage approved (in log of \$ thousands). Explanatory variables for each MSA are: [past price change (log)] the log of the ratio of the OFEHO house price index in 1999:4 to the index in 2005:4, [population (log)] the log of the population of the MSA from the 2006 American Community Survey dataset [ACS], [unemployment\% (log)] the log of the MSA unemployment rate in 2006 from Bureau of Labor Statistics (BLS), [65 and above\% (log)] the log of the percentage of the population over 65 from ACS, [high school\% $(\mathrm{log})]$ the log of the percentage of the population with a high school degree from ACS, [income per capita (log)] the log of income per capita (in \$ thousands) from ACS, and [Prime applications (log)] the log of prime mortgage applications. Heteroskedasticity-consistent standard deviations are reported in parentheses. $* * *$ denotes significance at the $1 \%$ level, $* *$ at the $5 \%$ level, and $*$ at $10 \%$ level.

\begin{tabular}{|c|c|c|c|c|c|c|c|c|}
\hline Explanatory variables & \multicolumn{8}{|c|}{ Dependant variables } \\
\hline & \multicolumn{4}{|c|}{ Loans (in log) } & \multicolumn{4}{|c|}{ Volume (in log) } \\
\hline Past price change (log) & $\begin{array}{c}* * * 1.614 \\
(0.266)\end{array}$ & $\begin{array}{c}* * * 0.359 \\
(0.083)\end{array}$ & $\begin{array}{c}* * *-0.094 \\
(0.016)\end{array}$ & $\begin{array}{c}* * *-0.083 \\
(0.017)\end{array}$ & $\begin{array}{c}* * * 2.973 \\
(0.286)\end{array}$ & $\begin{array}{c}* * * 1.452 \\
(0.090)\end{array}$ & $\begin{array}{c}* * *-0.091 \\
(0.018)\end{array}$ & $\begin{array}{l}-0.012 \\
(0.022)\end{array}$ \\
\hline Population (log) & & $\begin{array}{c}* * * 1.052 \\
(0.019)\end{array}$ & & $\begin{array}{c}* * * 0.076 \\
(0.014)\end{array}$ & & $\begin{array}{c}* * * 1.047 \\
(0.022)\end{array}$ & & $\begin{array}{c}* * * 0.070 \\
(0.011)\end{array}$ \\
\hline Unemployment\% (log) & & $\begin{array}{c}* * *-0.260 \\
(0.086)\end{array}$ & & $\begin{array}{c}* * *-0.041 \\
(0.013)\end{array}$ & & $\begin{array}{c}* * *-0.245 \\
(0.068)\end{array}$ & & $\begin{array}{c}* *-0.033 \\
(0.013)\end{array}$ \\
\hline 65 and above\% (log) & & $\begin{array}{c}* * *-0.260 \\
(0.086)\end{array}$ & & $\begin{array}{c}* 0.027 \\
(0.016)\end{array}$ & & $\begin{array}{c}* * *-0.585 \\
(0.099)\end{array}$ & & $\begin{array}{c}0.009 \\
(0.017)\end{array}$ \\
\hline High school\% (log) & & $\begin{array}{c}* 0.497 \\
(0.297)\end{array}$ & & $\begin{array}{c}* * * 0.317 \\
(0.073)\end{array}$ & & $\begin{array}{c}0.053 \\
(0.370)\end{array}$ & & $\begin{array}{c}* * * 0.291 \\
(0.077)\end{array}$ \\
\hline Income per capita (log) & & $\begin{array}{c}0.176 \\
(0.164)\end{array}$ & & $\begin{array}{c}* * * 0.083 \\
(0.031)\end{array}$ & & $\begin{array}{c}* * * 1.092 \\
(0.194)\end{array}$ & & $\begin{array}{c}* * * 0.159 \\
(0.033)\end{array}$ \\
\hline Prime applications (log) & & & $\begin{array}{c}* * * 0.975 \\
(0.003)\end{array}$ & $\begin{array}{c}* * * 0.905 \\
(0.013)\end{array}$ & & & $\begin{array}{c}* * * 0.978 \\
(0.003)\end{array}$ & $\begin{array}{c}* * * 0.912 \\
(0.011)\end{array}$ \\
\hline Sample size & 376 & 344 & 376 & 344 & 376 & 344 & 376 & 344 \\
\hline Adjusted R2 & 0.10 & 0.93 & 0.99 & 0.99 & 0.14 & 0.93 & 0.99 & 0.99 \\
\hline
\end{tabular}


Table 7. Approvals of subprime mortgages and past price changes

This table reports cross-sectional MSA level linear regressions regarding the determinants of the approvals of subprime mortgages in 2006. The approvals are measured with the number of mortgage approved (in log) and the volume of mortgage approved (in log of \$ thousands). Explanatory variables for each MSA are: [past price change (log)] the log of the ratio of the OFEHO house price index in 1999:4 to the index in 2005:4, [population (log)] the log of the population of the MSA from the 2006 American Community Survey dataset [ACS], [unemployment\% (log)] the log of the MSA unemployment rate in 2006 from Bureau of Labor Statistics (BLS), [65 and above\% (log)] the log of the percentage of the population over 65 from ACS, [high school\% (log)] the log of the percentage of the population with a high school degree from ACS, [income per capita (log)] the log of income per capita (in \$ thousands) from ACS, and [Subprime applications (log)] the log of subprime mortgage

applications. Heteroskedasticity-consistent standard deviations are reported in parentheses. *** denotes significance at the $1 \%$ level, $* *$ at the $5 \%$ level, and $*$ at $10 \%$ level.

\begin{tabular}{|c|c|c|c|c|c|c|c|c|}
\hline Explanatory variables & \multicolumn{8}{|c|}{ Dependant variables } \\
\hline & \multicolumn{4}{|c|}{ Loans (in log) } & \multicolumn{4}{|c|}{ Volume (in log) } \\
\hline Past price change (log) & $\begin{array}{c}* * * 2.658 \\
(0.320)\end{array}$ & $\begin{array}{c}* * * 1.087 \\
(0.138)\end{array}$ & $\begin{array}{c}0.012 \\
(0.022)\end{array}$ & $\begin{array}{l}-0.007 \\
(0.034)\end{array}$ & $\begin{array}{c}* * * 4.019 \\
(0.332)\end{array}$ & $\begin{array}{c}* * 2.252 \\
(0.146)\end{array}$ & $\begin{array}{c}* * 0.047 \\
(0.024)\end{array}$ & $\begin{array}{c}0.023 \\
(0.034)\end{array}$ \\
\hline Population (log) & & $\begin{array}{c}* * * 1.334 \\
(0.034)\end{array}$ & & $\begin{array}{c}* *-0.044 \\
(0.022)\end{array}$ & & $\begin{array}{c}* * * 1.329 \\
(0.036)\end{array}$ & & $\begin{array}{l}-0.029 \\
(0.018)\end{array}$ \\
\hline Unemployment\% (log) & & $\begin{array}{c}0.129 \\
(0.094)\end{array}$ & & $\begin{array}{c}* * *-0.080 \\
(0.019)\end{array}$ & & $\begin{array}{c}0.119 \\
(0.105)\end{array}$ & & $\begin{array}{c}* * *-0.089 \\
(0.019)\end{array}$ \\
\hline 65 and above\% (log) & & $\begin{array}{c}-0.019 \\
(0.158)\end{array}$ & & $\begin{array}{c}-0.004 \\
(0.029)\end{array}$ & & $\begin{array}{c}* *-0.341 \\
(0.167)\end{array}$ & & $\begin{array}{c}0.002 \\
(0.033)\end{array}$ \\
\hline High school\% (log) & & $\begin{array}{c}* * *-1.918 \\
(0.570)\end{array}$ & & $\begin{array}{c}-0.191 \\
(0.128)\end{array}$ & & $\begin{array}{c}* * *-2.454 \\
(0.617)\end{array}$ & & $\begin{array}{l}*-0.245 \\
(0.132)\end{array}$ \\
\hline Income per capita (log) & & $\begin{array}{l}-0.245 \\
(0.271)\end{array}$ & & $\begin{array}{l}-0.043 \\
(0.057)\end{array}$ & & $\begin{array}{c}0.412 \\
(0.310)\end{array}$ & & $\begin{array}{c}-0.096 \\
(0.057)\end{array}$ \\
\hline $\begin{array}{c}\text { Subprime applications } \\
\text { (log) }\end{array}$ & & & $\begin{array}{c}* * * 1.008 \\
(0.005)\end{array}$ & $\begin{array}{c}* * * 1.044 \\
(0.017)\end{array}$ & & & $\begin{array}{c}* * * 1.004 \\
(0.004)\end{array}$ & $\begin{array}{c}* * * 1.025 \\
(0.012)\end{array}$ \\
\hline Sample size & 376 & 344 & 376 & 344 & 376 & 344 & 376 & 344 \\
\hline Adjusted R2 & 0.16 & 0.87 & 0.99 & 0.99 & 0.28 & 0.88 & 0.99 & 0.99 \\
\hline
\end{tabular}


Table 8. Differences in approvals of prime and subprime mortgages

This table reports cross-sectional MSA level linear regressions concerning the differences between the effect of past price changes on prime mortgage approvals and the effect on subprime mortgage approvals in 2006. The dependant variable is the approvals for subprime mortgages minus the approvals for prime mortgages in the same MSA. The approvals are measured with the number of mortgage approved (in log) and the volume of mortgage approved (in log of \$ thousands). Explanatory variables for each MSA are: [past price change (log)] the log of the ratio of the OFEHO house price index in 1999:4 to the index in 2005:4, [population (log)] the log of the population of the MSA from the 2006 American Community Survey dataset [ACS], [unemployment\% (log)] the log of the MSA unemployment rate in 2006 from Bureau of Labor Statistics (BLS), [65 and above\% $(\log )]$ the log of the percentage of the population over 65 from ACS, [high school\% $(\log )$ ] the log of the percentage of the population with a high school degree from ACS, [income per capita (log)] the log of income per capita (in \$ thousands) from ACS, [Difference in applications] the log of subprime mortgage application minus the log of prime mortgage applications. Heteroskedasticity-consistent standard deviations are reported in parentheses. $* * *$ denotes significance at the $1 \%$ level, $* *$ at the $5 \%$ level, and $*$ at $10 \%$ level.

\begin{tabular}{|c|c|c|c|c|c|c|c|c|}
\hline Explanatory variables & \multicolumn{8}{|c|}{ Dependant variables } \\
\hline & \multicolumn{4}{|c|}{ Loans (in log) } & \multicolumn{4}{|c|}{ Volume (in log) } \\
\hline Past price change (log) & $\begin{array}{c}* * * 1.044 \\
(0.112)\end{array}$ & $\begin{array}{c}* * * 0.728 \\
(0.112)\end{array}$ & $\begin{array}{c}* * * 0.085 \\
(0.030)\end{array}$ & $\begin{array}{c}* * * 0.124 \\
(0.036)\end{array}$ & $\begin{array}{c}* * * 1.046 \\
(0.119)\end{array}$ & $\begin{array}{c}* * * 0.800 \\
(0.116)\end{array}$ & $\begin{array}{c}* * * 0.148 \\
(0.028)\end{array}$ & $\begin{array}{c}* * * 0.194 \\
(0.031)\end{array}$ \\
\hline Population (log) & & $\begin{array}{c}* * * 0.283 \\
(0.027)\end{array}$ & & $\begin{array}{c}* * 0.021 \\
(0.009)\end{array}$ & & $\begin{array}{c}* * * 0.282 \\
(0.027)\end{array}$ & & $\begin{array}{c}* * 0.021 \\
(0.010)\end{array}$ \\
\hline Unemployment\% (log) & & $\begin{array}{c}* * * 0.387 \\
(0.086)\end{array}$ & & $\begin{array}{c}* * *-0.087 \\
(0.022)\end{array}$ & & $\begin{array}{c}* * * 0.364 \\
(0.088)\end{array}$ & & $\begin{array}{c}* * *-0.100 \\
(0.024)\end{array}$ \\
\hline 65 and above\% (log) & & $\begin{array}{c}* * 0.241 \\
(0.108)\end{array}$ & & $\begin{array}{c}* *-0.085 \\
(0.036)\end{array}$ & & $\begin{array}{c}* * 0.244 \\
(0.110)\end{array}$ & & $\begin{array}{c}* *-0.094 \\
(0.043)\end{array}$ \\
\hline High school\% (log) & & $\begin{array}{c}* * *-2.414 \\
(0.505)\end{array}$ & & $\begin{array}{c}* * *-0.417 \\
(0.151)\end{array}$ & & $\begin{array}{c}* * *-2.507 \\
(0.486)\end{array}$ & & $\begin{array}{c}* * *-0.488 \\
(0.152)\end{array}$ \\
\hline Income per capita $(\mathrm{log})$ & & $\begin{array}{l}*-0.421 \\
(0.222)\end{array}$ & & $\begin{array}{c}-0.101 \\
(0.064)\end{array}$ & & $\begin{array}{c}* * *-0.681 \\
(0.220)\end{array}$ & & $\begin{array}{c}*-0.116 \\
(0.065)\end{array}$ \\
\hline $\begin{array}{l}\text { Difference in } \\
\text { applications }\end{array}$ & & & $\begin{array}{c}* * * 1.099 \\
(0.020)\end{array}$ & $\begin{array}{c}* * * 1.078 \\
(0.024)\end{array}$ & & & $\begin{array}{c}* * * 1.090 \\
(0.017)\end{array}$ & $\begin{array}{c}* * * 1.066 \\
(0.021)\end{array}$ \\
\hline Sample size & 376 & 344 & 376 & 344 & 376 & 344 & 376 & 344 \\
\hline Adjusted R2 & 0.16 & 0.51 & 0.95 & 0.95 & 0.15 & 0.51 & 0.95 & 0.95 \\
\hline
\end{tabular}


Table 9. Approval Loan to income ratio and past price changes

This table reports cross-sectional MSA level linear regressions regarding the average loan to income ratio (in log) of prime and subprime mortgage approvals in 2006. Explanatory variables for each MSA are: [past price change (log)] the log of the ratio of the OFEHO house price index in 1999:4 to the index in 2005:4, [population (log)] the log of the population of the MSA from the 2006 American Community Survey dataset [ACS], [unemployment\% (log)] the log of the MSA unemployment rate in 2006 from Bureau of Labor Statistics (BLS), [65 and above\% (log)] the log of the percentage of the population over 65 from ACS, [high school\% $(\log )]$ the log of the percentage of the population with a high school degree from ACS, [income per capita (log)] the log of income per capita (in \$ thousands) from ACS, and [Application LTI (log)] the average loan to income ratio of mortgage applications. Heteroskedasticity-consistent standard deviations are reported in parentheses. $* * *$ denotes significance at the $1 \%$ level, $* *$ at the $5 \%$ level, and $*$ at $10 \%$ level.

\begin{tabular}{|c|c|c|c|c|c|c|c|c|}
\hline Explanatory variables & \multicolumn{8}{|c|}{ Dependant variables } \\
\hline & \multicolumn{4}{|c|}{ Prime approvals } & \multicolumn{4}{|c|}{ Subprime approvals } \\
\hline Past price change (log) & $\begin{array}{c}* * * 0.321 \\
(0.025)\end{array}$ & $\begin{array}{c}* * * 0.302 \\
(0.028)\end{array}$ & $\begin{array}{c}* * *-0.016 \\
(0.003)\end{array}$ & $\begin{array}{l}*-0.007 \\
(0.004)\end{array}$ & $\begin{array}{c}* * * 0.269 \\
(0.021)\end{array}$ & $\begin{array}{c}* * * 0.192 \\
(0.026)\end{array}$ & $\begin{array}{c}* * * 0.059 \\
(0.011)\end{array}$ & $\begin{array}{c}* * * 0.059 \\
(0.013)\end{array}$ \\
\hline Population (log) & & $\begin{array}{c}* *-0.016 \\
(0.007)\end{array}$ & & $\begin{array}{c}-0.001 \\
(0.001)\end{array}$ & & $\begin{array}{c}0.002 \\
(0.007)\end{array}$ & & $\begin{array}{c}-0.001 \\
(0.003)\end{array}$ \\
\hline Unemployment\% (log) & & $\begin{array}{c}* * * 0.067 \\
(0.022)\end{array}$ & & $\begin{array}{c}-0.002 \\
(0.003)\end{array}$ & & $\begin{array}{c}* * * 0.068 \\
(0.023)\end{array}$ & & $\begin{array}{c}0.004 \\
(0.007)\end{array}$ \\
\hline 65 and above\% (log) & & $\begin{array}{c}* * *-0.105 \\
(0.030)\end{array}$ & & $\begin{array}{c}* * *-0.010 \\
(0.003)\end{array}$ & & $\begin{array}{c}0.016 \\
(0.026)\end{array}$ & & $\begin{array}{c}-0.013 \\
(0.012)\end{array}$ \\
\hline High school\% (log) & & $\begin{array}{c}* * 0.329 \\
(0.131)\end{array}$ & & $\begin{array}{c}* * * 0.049 \\
(0.015)\end{array}$ & & $\begin{array}{c}-0.174 \\
(0.128)\end{array}$ & & $\begin{array}{c}-0.011 \\
(0.040)\end{array}$ \\
\hline Income per capita (log) & & $\begin{array}{c}* * 0.154 \\
(0.063)\end{array}$ & & $\begin{array}{c}-0.006 \\
(0.005)\end{array}$ & & $\begin{array}{c}* * * 0.173 \\
(0.059)\end{array}$ & & $\begin{array}{c}-0.004 \\
(0.016)\end{array}$ \\
\hline Application LTI (log) & & & $\begin{array}{c}* * * 1.031 \\
(0.006)\end{array}$ & $\begin{array}{c}* * * 1.013 \\
(0.008)\end{array}$ & & & $\begin{array}{c}* * * 0.958 \\
(0.035)\end{array}$ & $\begin{array}{c}* * * 0.952 \\
(0.036)\end{array}$ \\
\hline Sample size & 376 & 344 & 376 & 344 & 376 & 344 & 376 & 344 \\
\hline Adjusted R2 & 0.30 & 0.37 & 0.99 & 0.99 & 0.24 & 0.23 & 0.91 & 0.90 \\
\hline
\end{tabular}


Table 10. Origination loan to value ratio and past price changes

This table reports cross-sectional MSA level linear regressions concerning the effect of past price changes on prime and subprime mortgage origination Loan to Value Ratio (LTV) in log in 2006. Explanatory variables for each MSA are: [past price change (log)] the log of the ratio of the OFEHO house price index in 1999:4 to the index in 2005:4, [population (log)] the log of the population of the MSA from the 2006 American Community Survey dataset [ACS], [unemployment\% (log)] the log of the MSA unemployment rate in 2006 from Bureau of Labor Statistics (BLS), [65 and above\% (log)] the log of the percentage of the population over 65 from ACS, [high school\% (log)] the log of the percentage of the population with a high school degree from ACS, [income per capita (log)] the log of income per capita (in \$ thousands) from ACS, [Difference in applications] the log of subprime mortgage application minus the log of prime mortgage applications, and [Application LTV (log)] the average LTV of mortgage applications. Heteroskedasticity-consistent standard deviations are reported in parentheses. *** denotes significance at the $1 \%$ level, $* *$ at the $5 \%$ level, and $*$ at $10 \%$ level.

\begin{tabular}{|c|c|c|c|c|c|c|c|c|}
\hline Explanatory variables & \multicolumn{8}{|c|}{ Dependant variables } \\
\hline & \multicolumn{4}{|c|}{ Prima approvals } & \multicolumn{4}{|c|}{ Subprime approvals } \\
\hline Past price change (log) & $\begin{array}{c}* * *-0.154 \\
(0.008)\end{array}$ & $\begin{array}{c}* * *-0.122 \\
(0.009)\end{array}$ & $\begin{array}{c}* * *-0.073 \\
(0.006)\end{array}$ & $\begin{array}{c}* * *-0.072 \\
(0.006)\end{array}$ & $\begin{array}{c}* * *-0.143 \\
(0.008)\end{array}$ & $\begin{array}{c}* * *-0.148 \\
(0.009)\end{array}$ & $\begin{array}{c}* * *-0.107 \\
(0.013)\end{array}$ & $\begin{array}{c}* * *-0.113 \\
(0.012)\end{array}$ \\
\hline Population (log) & & $\begin{array}{c}0.000 \\
(0.002)\end{array}$ & & $\begin{array}{c}0.001 \\
(0.001)\end{array}$ & & $\begin{array}{c}0.000 \\
(0.002)\end{array}$ & & $\begin{array}{l}-0.000 \\
(0.002)\end{array}$ \\
\hline Unemployment\% (log) & & $\begin{array}{c}0.004 \\
(0.006)\end{array}$ & & $\begin{array}{c}0.004 \\
(0.004)\end{array}$ & & $\begin{array}{c}* * * 0.017 \\
(0.006)\end{array}$ & & $\begin{array}{l}* * 0.012 \\
(0.005)\end{array}$ \\
\hline 65 and above\% (log) & & $\begin{array}{c}0.002 \\
(0.010)\end{array}$ & & $\begin{array}{l}* 0.010 \\
(0.006)\end{array}$ & & $\begin{array}{c}* * * 0.052 \\
(0.008)\end{array}$ & & $\begin{array}{c}* * * 0.041 \\
(0.007)\end{array}$ \\
\hline High school\% (log) & & $\begin{array}{c}0.058 \\
(0.038)\end{array}$ & & $\begin{array}{l}-0.006 \\
(0.024)\end{array}$ & & $\begin{array}{c}0.055 \\
(0.037)\end{array}$ & & $\begin{array}{c}0.041 \\
(0.035)\end{array}$ \\
\hline Income per capita (log) & & $\begin{array}{c}* * *-0.125 \\
(0.020)\end{array}$ & & $\begin{array}{c}* * *-0.045 \\
(0.011)\end{array}$ & & $\begin{array}{l}-0.010 \\
(0.020)\end{array}$ & & $\begin{array}{c}-0.016 \\
(0.017)\end{array}$ \\
\hline Application LTV (log) & & & $\begin{array}{c}* * 0.687 \\
(0.035)\end{array}$ & $\begin{array}{c}* * * 0.625 \\
(0.037)\end{array}$ & & & $\begin{array}{c}* * * 0.212 \\
(0.058)\end{array}$ & $\begin{array}{c}* * * 0.182 \\
(0.056)\end{array}$ \\
\hline Sample size & 349 & 344 & 347 & 344 & 349 & 344 & 347 & 344 \\
\hline Adjusted R2 & 0.50 & 0.63 & 0.84 & 0.86 & 0.49 & 0.57 & 0.59 & 0.63 \\
\hline
\end{tabular}


Table 11. Origination home value to income ratio and past price changes

This table reports cross-sectional MSA level linear regressions concerning the effect of past price changes on prime and subprime mortgage origination home value to income ratio (VTI) in 2006. Explanatory variables for each MSA are: [past price change (log)] the log of the ratio of the OFEHO house price index in 1999:4 to the index in 2005:4, [population (log)] the log of the population of the MSA from the 2006 American Community Survey dataset [ACS], [unemployment\% (log)] the log of the MSA unemployment rate in 2006 from Bureau of Labor Statistics (BLS), [65 and above\% (log)] the log of the percentage of the population over 65 from ACS, [high school\% (log)] the log of the percentage of the population with a high school degree from ACS, [income per capita (log)] the log of income per capita (in \$ thousands) from ACS, [Difference in applications] the log of subprime mortgage application minus the log of prime mortgage applications, and [Application VTI (log)] the average VTI of mortgage applications. Heteroskedasticity-consistent standard deviations are reported in parentheses. $* * *$ denotes significance at the $1 \%$ level, $* *$ at the $5 \%$ level, and $*$ at $10 \%$ level.

\begin{tabular}{|c|c|c|c|c|c|c|c|c|}
\hline Explanatory variables & \multicolumn{8}{|c|}{ Dependant variables } \\
\hline & \multicolumn{4}{|c|}{ Prime approvals } & \multicolumn{4}{|c|}{ Subprime approvals } \\
\hline Past price change (log) & $\begin{array}{c}* * * 0.463 \\
(0.030)\end{array}$ & $\begin{array}{c}* * * 0.424 \\
(0.030)\end{array}$ & $\begin{array}{c}* * * 0.036 \\
(0.008)\end{array}$ & $\begin{array}{c}* * * 0.055 \\
(0.009)\end{array}$ & $\begin{array}{c}* * * 0.391 \\
(0.024)\end{array}$ & $\begin{array}{c}* * * 0.340 \\
(0.027)\end{array}$ & $\begin{array}{c}* * * 0.092 \\
(0.013)\end{array}$ & $\begin{array}{c}* * * 0.082 \\
(0.014)\end{array}$ \\
\hline Population (log) & & $\begin{array}{c}* *-0.017 \\
(0.008)\end{array}$ & & $\begin{array}{c}* * *-0.004 \\
(0.001)\end{array}$ & & $\begin{array}{c}0.001 \\
(0.007)\end{array}$ & & $\begin{array}{c}0.002 \\
(0.003)\end{array}$ \\
\hline Unemployment\% (log) & & $\begin{array}{c}* * * 0.063 \\
(0.023)\end{array}$ & & $\begin{array}{c}-0.001 \\
(0.005)\end{array}$ & & $\begin{array}{c}* * 0.052 \\
(0.023)\end{array}$ & & $\begin{array}{l}* * 0.020 \\
(0.010)\end{array}$ \\
\hline 65 and above\% (log) & & $\begin{array}{c}* * *-0.107 \\
(0.031)\end{array}$ & & $\begin{array}{c}* * *-0.029 \\
(0.006)\end{array}$ & & $\begin{array}{c}-0.036 \\
(0.029)\end{array}$ & & $\begin{array}{c}-0.014 \\
(0.013)\end{array}$ \\
\hline High school\% (log) & & $\begin{array}{c}0.270 \\
(0.138)\end{array}$ & & $\begin{array}{c}* * * 0.105 \\
(0.033)\end{array}$ & & $\begin{array}{l}*-0.229 \\
(0.133)\end{array}$ & & $\begin{array}{l}-0.037 \\
(0.058)\end{array}$ \\
\hline Income per capita (log) & & $\begin{array}{c}* * * 0.280 \\
(0.069)\end{array}$ & & $\begin{array}{c}0.005 \\
(0.013)\end{array}$ & & $\begin{array}{c}* * * 0.184 \\
(0.067)\end{array}$ & & $\begin{array}{l}* * 0.062 \\
(0.029)\end{array}$ \\
\hline Application VTI (log) & & & $\begin{array}{c}* * * 0.982 \\
(0.014)\end{array}$ & $\begin{array}{c}* * * 0.959 \\
(0.016)\end{array}$ & & & $\begin{array}{c}* * * 0.798 \\
(0.027)\end{array}$ & $\begin{array}{c}* * * 0.782 \\
(0.029)\end{array}$ \\
\hline Sample size & 347 & 344 & 347 & 344 & 347 & 344 & 347 & 344 \\
\hline Adjusted R2 & 0.42 & 0.53 & 0.97 & 0.98 & 0.39 & 0.42 & 0.87 & 0.87 \\
\hline
\end{tabular}


Table 12. Probit analysis of loan approvals

This table reports the probit analysis for the approval of prime and subprime mortgage applications respectively. The analysis uses all applications for conventional mortgages for purchasing owner occupied single family houses from each MSA.

Dependant variables are 1 if an application is approved and 0 if not. Explanatory variables are: [past price change (log)] the $\log$ of the ratio of the OFEHO house price index in 2005:4 to the index in 1999:4, [population minority\% (log)] the log of the percentage of the minority population in the census tract of the loan application, [median income (log)] HUD median family income in dollars (log) in the MSA of the loan application, [tract to MSA median income percentage (log)] the log of the percentage of tract median family income compared to MSA/MD median family income, [loan size to income ratio (log)] the log of the size of the application to the income of the applicant, [preapproval dummy] a dummy that equals 1 if preapproval was requested, [applicants per capita (log)] the log of the number of applicants in an MSA divided by the total population in the MSA, and [VTL] the log of the requested loan size to the average MSA home value or originated loans. Standard deviations are reported in parentheses. $* * *$ denotes significance at the $1 \%$ level, $* *$ at the $5 \%$ level, and $*$ at $1 \%$ level.

\begin{tabular}{|c|c|c|c|c|c|}
\hline Explanatory Variables & \multicolumn{2}{|c|}{ Prime Approvals } & \multicolumn{3}{|c|}{ Subprime Approvals } \\
\hline Past price change (log) & $\begin{array}{l}* * *-0.332 \\
(0.006)\end{array}$ & $\begin{array}{l}* * *-0.612 \\
(0.006)\end{array}$ & $\begin{array}{c}* * * 0.0663 \\
(0.010)\end{array}$ & $\begin{array}{l}* * * 0.124 \\
(0.010)\end{array}$ & \\
\hline Population minority \% (log) & $\begin{array}{l}* * *-0.095 \\
(0.001)\end{array}$ & $\begin{array}{c}* * *-0.088 \\
(0.001)\end{array}$ & $\begin{array}{c}* * *-0.047 \\
(0.001)\end{array}$ & $\begin{array}{c}* * *-0.043 \\
(0.001)\end{array}$ & \\
\hline Median income (log) & $\begin{array}{c}* * * 0.382 \\
(0.004)\end{array}$ & $\begin{array}{c}* * * 0.490 \\
(0.004)\end{array}$ & $\begin{array}{c}* * *-0.025 \\
(0.006)\end{array}$ & $\begin{array}{c}* * *-0.021 \\
(0.006)\end{array}$ & \\
\hline $\begin{array}{c}\text { Tract to MSA median income } \\
\text { percentage (log) }\end{array}$ & $\begin{array}{l}* * * 0.335 \\
(0.002)\end{array}$ & $\begin{array}{l}* * * 0.418 \\
(0.002)\end{array}$ & $\begin{array}{c}* * * 0.117 \\
(0.003)\end{array}$ & $\begin{array}{c}* * * 0.109 \\
(0.004)\end{array}$ & \\
\hline $\begin{array}{l}\text { Loan size to income ratio } \\
(\log )\end{array}$ & $\begin{array}{c}* * *-0.025 \\
(0.001)\end{array}$ & $\begin{array}{c}* * *-0.021 \\
(0.001)\end{array}$ & $\begin{array}{l}* * *-0.108 \\
(0.001)\end{array}$ & $\begin{array}{c}* * *-0.113 \\
(0.001)\end{array}$ & \\
\hline Preapproval dummy & $\begin{array}{l}* * * 0.359 \\
(0.003)\end{array}$ & $\begin{array}{l}* * * 0.370 \\
(0.002)\end{array}$ & $\begin{array}{c}* * * 0.842 \\
(0.014)\end{array}$ & $\begin{array}{l}* * * 0.845 \\
(0.014)\end{array}$ & \\
\hline Applicants per capita (log) & & $\begin{array}{l}* * *-0.027 \\
(0.001)\end{array}$ & & $\begin{array}{l}* * *-0.007 \\
(0.001)\end{array}$ & \\
\hline Number of Observations & $6,449,088$ & $6,449,088$ & $1,412,857$ & $1,412,857$ & \\
\hline
\end{tabular}

